\title{
Four plant defensins from an indigenous South African Brassicaceae species display divergent activities against two test pathogens despite high sequence similarity in the encoding genes
}

Abré de Beer and Melané A Vivier*

\begin{abstract}
Background: Plant defensins are an important component of the innate defence system of plants where they form protective antimicrobial barriers between tissue types of plant organs as well as around seeds. These peptides also have other activities that are important for agricultural applications as well as the medical sector. Amongst the numerous plant peptides isolated from a variety of plant species, a significant number of promising defensins have been isolated from Brassicaceae species. Here we report on the isolation and characterization of four defensins from Heliophila coronopifolia, a native South African Brassicaceae species.

Results: Four defensin genes (HC-AFP1-4) were isolated with a homology based PCR strategy. Analysis of the deduced amino acid sequences showed that the peptides were $72 \%$ similar and grouped closest to defensins isolated from other Brassicaceae species. The Hc-AFP1 and 3 peptides shared high homology (94\%) and formed a unique grouping in the Brassicaceae defensins, whereas Hc-AFP2 and 4 formed a second homology grouping with defensins from Arabidopsis and Raphanus. Homology modelling showed that the few amino acids that differed between the four peptides had an effect on the surface properties of the defensins, specifically in the alpha-helix and the loop connecting the second and third beta-strands. These areas are implicated in determining differential activities of defensins. Comparing the activities after recombinant production of the peptides, Hc-AFP2 and 4 had $\mid \mathrm{C}_{50}$ values of $5-20 \mathrm{\mu g} \mathrm{ml}^{-1}$ against two test pathogens, whereas Hc-AFP1 and 3 were less active. The activity against Botrytis cinerea was associated with membrane permeabilization, hyper-branching, biomass reduction and even lytic activity. In contrast, only Hc-AFP2 and 4 caused membrane permeabilization and severe hyper-branching against the wilting pathogen Fusarium solani, while Hc-AFP1 and 3 had a mild morphogenetic effect on the fungus, without any indication of membrane activity. The peptides have a tissue-specific expression pattern since differential gene expression was observed in the native host. HC-AFP1 and 3 expressed in mature leaves, stems and flowers, whereas HC-AFP2 and 4 exclusively expressed in seedpods and seeds.

Conclusions: Two novel Brassicaceae defensin sequences were isolated amongst a group of four defensin encoding genes from the indigenous South African plant $H$. coronopifolia. All four peptides were active against two test pathogens, but displayed differential activities and modes of action. The expression patterns of the peptide encoding genes suggest a role in protecting either vegetative or reproductive structures in the native host against pathogen attack, or roles in unknown developmental and physiological processes in these tissues, as was shown with other defensins.
\end{abstract}

\footnotetext{
* Correspondence: mav@sun.ac.za

Institute for Wine Biotechnology, Department of Oenology and Viticulture, Faculty of AgriSciences, Stellenbosch University, Stellenbosch 7600, South Africa
} 


\section{Background}

Plants have developed complex defence systems to protect them against a multitude of plant pathogens [1-8]. These defence systems consists of an array of both chemical and biochemical substances that protect the plant against colonization and subsequent spread of disease and can broadly be divided into the innate and active defence responses [7,9-13]. The innate defence responses play an important role in establishing preformed barriers of defence to prevent colonization by pathogens. Antimicrobial peptides (AMPs) are an important component of the innate defence response. They are small, mostly basic peptides that range in size from 2-9 $\mathrm{kDa}$ and have been classified into nine groups. Plant defensins [10,14-21], thionins [22-27] and lipid transfer proteins [28-34] are the best characterized of these nine groups.

Plant defensins are small, basic, heat stable peptides with a conserved tertiary structure that consists of a single $\alpha$-helix and three anti-parallel $\beta$-strands [17,35-37]. The defensin tertiary structure is internally stabilized by disulphide bridges linking the $\alpha$-helix to two of the $\beta$ strands to form a structure know as the cysteine stabilizing motif, a conserved motif identified in AMPs isolated from various prokaryotes and higher eukaryotes [38-41]. In addition to the cysteine stabilizing motif two additional conserved motives have been identified in the plant defensin structure, namely the $\alpha$-core, encompassing the loop connecting the first $\beta$-strand and $\alpha$-helix and the $\gamma$-core containing the all important hairpin loop connecting $\beta$-strand 2 and $3\left(L \beta_{2} \beta_{3}\right)$. Notwithstanding this conserved tertiary structure, plant defensins share very little homology at amino acid level. It is however this variability in primary amino acid sequence that contributes to the different biological functions that have been attributed to these peptides, where a single amino acid can change the spectrum of activity exhibited by closely related defensin peptides.

The role of plant defensins in the preformed defence of plants is well documented. They play an important role in the protection of germinating plant seeds, developing seedlings and reproductive structures of plants [42-44] and have been isolated from roots [44-46], vegetative tissues and reproductive structures such as flowers and fruits [45,47-55]. The majority of characterized plant defensins show a constitutive pattern of expression, with an induction in expression in response to pathogen attack, wounding and some abiotic stresses [20,44-46]. Recently it was shown that pathogen-induced expression of Arabidopsis plant defensins is dependent on ENHANCED DISEASE RESISTANCE1 (EDR1), which interferes with the repressor function of $M Y C 2$ allowing for defensin gene expression [56]. Some defensins, however, show a strict tissue-specific and developmentally regulated pattern of expression $[47,50,54,57,58]$ which in some cases were linked to specific biological functions other than plant defence, as was demonstrated for the defensins from tomato and maize that play a role during pollination $[50,57]$.

Plant defensins are best known for their antimicrobial activity against a broad spectrum of plant pathogens that include bacteria $[59,60]$, yeast [61-64], oomycetes $[65,66]$ and necrotrophic pathogens $[47,61,64,65,67-71]$. In addition to these strong antimicrobial activities that established them as important agricultural biotechnology targets, some members also show activities important for medical applications, including protease inhibitory activity $[23,72]$, anti cancer activity $[61,73]$ and HIV inhibition [61,74-76]. Other agriculturally important activities include insecticidal activity $[35,36,77,78]$, activity against parasitic plants [79] and heavy metal tolerance [80].

The isolation and characterization of a wide range of defensin peptides are crucial for the continued development of economically and medically important products. Analysis of the sequenced plant genomes revealed that defensins are present as multigene families and are overrepresented in the genomes of some plants species $[46,81]$. With the wealth of defensin nucleotide sequences available, strategies of gene isolation coupled with recombinant production are increasingly been used for the characterization of closely related plant defensin peptides.

This work describes the successful isolation of four plant defensin genes from the South African Brassicaceae species Heliophila coronopifolia. An isolation strategy based on the sequence homology that exists within the nucleotides encoding the signal peptides of defensins from domesticated Brassicaceae species was used to isolate four defensin sequences, of which two were shown to be novel for Brassicaceae defensins. Each of the defensin peptide was successfully purified through recombinant production in Escherichia coli and characterized for their activity and mode of action against two test pathogens. These results as well as expression analysis in the host showed that the four peptides have differential expression patterns in vegetative and reproductive organs, as well as differential activities and modes of inhibition under the conditions tested. In addition, the divergence in structural motifs and surface properties observed for these peptides provide interest to study structure-activity determinants in these peptides.

\section{Results}

Isolation and in silico characterization of the Hc-AFP encoding sequences

PCR-based isolation of cDNA from H. coronopifolia tissues allowed for the isolation of four putative defensin 
sequences ranging between 426 bp and 468 bp, containing open reading frames of 240 and $243 \mathrm{bp}$, respectively. TBLASTN analysis of the nucleotide sequences showed homology to sequences encoding for the super family of plant antifungal peptides known as plant defensins. The isolated gene sequences were thus termed $H$. coronopifolia antifungal peptide 1 to 4 (Hc-AFP 1 - 4) (Figure 1).

Analysis of the deduced amino acid sequences showed that $H c-A F P 1$ and 3 encode for 80 amino acid peptides, whereas $H c-A F P 2$ and 4 encode for 81 amino acid peptides (Figure 1). SignalP results showed that the first 30 amino acids of each peptide encode for a signal peptide followed by a 50 amino acid mature peptide for HcAFP1 and 3 and a 51 amino acid mature peptide for Hc-AFP2 and 4 (Table 1). The peptide parameters obtained from the Expasy-Compute $\mathrm{pI} / \mathrm{Mw}$ tool (Table 1 ) showed that the peptides had predicted mono-isotopic masses ranging between 5.48 and $5.73 \mathrm{kDa}$ and are highly basic with isoelectric points above 8.2.

Alignment analysis of the deduced amino acid sequences revealed that the newly isolated $H$. coronopifolia defensins shared the highest homology with defensins isolated from other members of the Brassicaceae family (Figure 2). Disulphide-bridge analyses conducted on the Hc-AFP peptides revealed that they share a disulphide bridge pattern common to all plant defensins (Figure 3). Further comparison of Hc-AFPs with members of the Brassicaceae defensins (Figures 2 and 3) revealed that Hc-AFP1 shared the closest homology to Hc-AFP3 at $94 \%$ similarity and Rs-AFP3 from Raphanus sativa at $82 \%$ similarity, whereas Hc-AFP2 showed the greatest homology to the defensins isolated from Sinapsis alba and $R$. sativa (Rs-AFP2) at 98\% similarity (Figures 2 and 3). Hc-AFP4 was more closely related to PDF1.1 from A. halleri, a defensin proposed to play a role in the zinc tolerance of $A$. halleri.

Analysis of homology models obtained for the different Hc-AFPs in combination with the alignment analysis of the Hc-AFPs showed that most of the amino acid differences occurred in the $\alpha$-helical regions of the peptides. By plotting the amino acid differences between the closely related Hc-AFP1 and 3 (94\% similarity) where Ser17, Gly18 and Asn22 in Hc-AFP1 is replaced by Tyr17, Asp18 and Ser22 in Hc-AFP3 onto their respective models, it was observed that the change from a polar Gly18 to an acidic Aspartic18 residue in HcAFP3 resulted in a less polar $\alpha$-helical region (Figure 4A and $4 \mathrm{~B}$ ). Root mean square deviation (RMSD) comparison between the structures of Hc-AFP1 and 3 revealed that these differences, although occurring in the $\alpha$-helical region, caused a greater RMSD deviation in the $\mathrm{N}$ and C-terminal ends of the peptide structure (Figure $4 C)$. Comparative analysis of the amino acids sequences of Hc-AFP2 and 4 showed that they also share $94 \%$ similarity, with Asn19 and 27 (numbering according to Hc-AFP2) replaced with Gly19 and Arg27 and Lys30 replaced with Arg30 in Hc-AFP4 (Figure 4D and 4E). Comparative analysis of the structural models of HcAFP2 and 4 revealed that these amino acid changes had very little effect on the overall structure of these peptides and only had a RMSD difference of $0.26 \AA$ in the $\alpha$-helical region of the peptides (Figure 4F), leading to an extended $\alpha$-helix in Hc-AFP2 when compared to HcAFP4 (Figure 4D and 4E). These amino acid substitutions did however result in a difference of the predicted surface properties between the Hc-AFP2 and 4 peptides. Hc-AFP4 is more basic and less hydrophilic in nature, whereas Hc-AFP2 is more polar in the regions surrounding the $\alpha$-helix (Figure $4 \mathrm{D}$ and $4 \mathrm{E}$ ).

The amino acids encoding for the $\alpha$-helical region of Hc-AFP1 and 3 are unique when compared to defensins isolated from the other Brassicaceae species. Structural alignment of the backbones of the Hc-AFP1 - 4 models revealed that these unique amino acids present in the $\alpha$ helical region of Hc-AFP1 and 3 (designated Group 1) resulted in a difference in tertiary structure when compared to Hc-AFP2 and 4 (designated Group 2) (Figure 4G). The $\alpha$-helical regions of Group1 vs Group 2 had a RMSD value of more than $1.7 \AA$, and importantly, a significant difference of more than $1.6 \AA$ was also observed in the $L \beta_{2} \beta_{3}$ loop, which is encoded by amino acids 38 to 41 (numbering according to Hc-AFP2) (Figure $4 \mathrm{H}$ ).

\section{Expression analysis of the Hc-AFP encoding genes}

Quantitative RT-PCR (q-RT-PCR) analysis conducted on the Heliophila defensin encoding genes revealed that the reproductive and storage organs of the $H$. coronopifolia plant, which include the flowers, siliques and seeds, contributed to $91 \%$ of the observed defensin transcript present (Figure 5A). When considering the expression patterns of the individual peptides encoding genes, $\mathrm{Hc}$ $A F P 1$ and 3 showed expression in vegetative and reproductive tissues tested (leaves, stems, flowers), as well as very low levels of expression in storage tissues (siliques and seeds) (Figure 5B). The distribution of these transcripts within the tissue types differed however, with Hc-AFP 1 being the dominant transcript in stem and flower tissue contributing $66 \%$ and $73 \%$ respectively of the total defensin transcript present in these tissues. $\mathrm{Hc}$ AFP3 was the dominant transcript in the leaf tissue contributing $73 \%$ of the observed defensin transcript present. In contrast $H c-A F P 2$ and 4 were the dominant transcripts present in the storage organs of $H$. coronopifolia and not expressed in leaves, stems or flowers (Figure $5 \mathrm{~B}$ ). Hc-AFP2 was the dominant transcript in green siliques contributing $79 \%$ of the total defensin transcript present, but only contributed $19 \%$ of the total defensin transcript observed in mature seeds. Hc-AFP4 was 


\section{HC-AFP1}

1 ATG GCT AAG TTT GCT TCC ATC ATT GCA CTT CTC TTC GCT GCT TTT 45

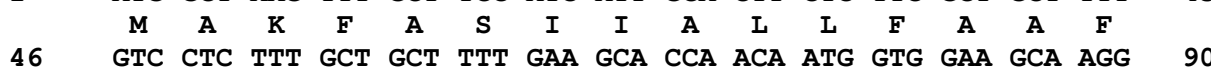

$\begin{array}{ccccccccccccccccc} & \text { V } & \text { L } & \text { F } & \text { A } & \text { A } & \text { F } & \text { E } & \text { A } & \text { P } & \text { T } & \text { M } & \text { V } & \text { E } & \text { A } & \text { R } & \\ 91 & \text { TAC } & \text { TGT } & \text { GAG } & \text { AGA } & \text { TCG } & \text { AGT } & \text { GGA } & \text { ACA } & \text { TGG } & \text { TCA } & \text { GGA } & \text { GTT } & \text { TGT } & \text { GGA } & \text { AAC } & 135\end{array}$

$\begin{array}{ccccccccccccccccc} & \text { Y } & \text { C } & \text { E } & \text { R } & \text { S } & \text { S } & \text { G } & \text { T } & \text { W } & \text { S } & \text { G } & \text { V } & \text { C } & \text { G } & \text { N } & \\ 136 & \text { AGT } & \text { GGT } & \text { AAG } & \text { TGT } & \text { AGT } & \text { AAT } & \text { CAA } & \text { TGT } & \text { CAG } & \text { AGA } & \text { CTT } & \text { GAA } & \text { GGA } & \text { GCA } & \text { GCA } & 180\end{array}$

$\begin{array}{ccccccccccccccccc} & \text { S } & \text { G } & \text { K } & \text { C } & \text { S } & \text { N } & \text { Q } & \text { C } & \text { Q } & \text { R } & \text { L } & \text { E } & \text { G } & \text { A } & \text { A } & \\ 181 & \text { CAT } & \text { GGA } & \text { TCT } & \text { TGC } & \text { AAC } & \text { TAT } & \text { GTC } & \text { TTC } & \text { CCA } & \text { GCT } & \text { CAC } & \text { AAG } & \text { TGT } & \text { ATC } & \text { TGT } & 225\end{array}$

226 TAC TAC CCA TGT TAA 240

$\mathrm{Y} Y \mathrm{P}$ C *

\section{Hc-AFP2}

1 ATG GCT AAG TTT GCT TCC ATC ATT GCC TTT TTC TTC GCT GCT CTT

46 GTT CTC TTT GCT GCT TTT GAA GCA CCA ACG ATA GTG GAA GCA CAA 90

91 AAG TTG TGT GAG AGA CCA AGT GGA ACA TGG TCA GGA GTT TGT GGA

136 AAC AAT AAT GCG TGT AGG AAC CAG TGC ATC AAC CTT GAA AAA GCA

181 CGA CAT GGA TCT TGC AAC TAT GTT TTC CCA GCT CAC AAG TGT ATC

226

$$
\begin{array}{lllllllllllllll}
R & \text { H } & \text { G } & \text { S } & \text { C } & \text { N } & \text { Y } & \text { V } & \text { F } & \text { P } & \text { A } & \text { H } & \text { K } & \text { C } & \text { I }
\end{array}
$$

\section{Hc-AFP3}

1 ATG GCT AAG TTT GCT TCC ATC ATC GCA CTT CTC TTC GCT GCT TTT

$\begin{array}{lccccccccccccccc}46 & \text { GTC } & \text { CTC } & \text { TTT } & \text { GCT } & \text { GCT } & \text { TTT } & \text { GAA } & \text { GCA } & \text { CCA } & \text { ACA } & \text { ATG } & \text { GTG } & \text { GAA } & \text { GCA } & \text { AGG }\end{array}$

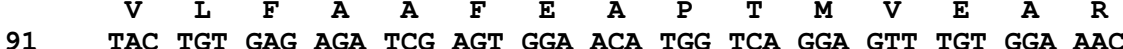

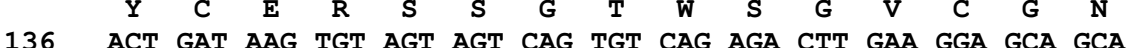

$\begin{array}{cccccccccccccccc} & T & D & K & C & S & S & Q & C & Q & R & L & E & G & A & A\end{array}$

226

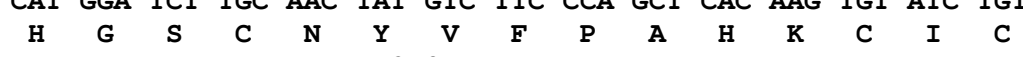

\section{Hc-AFP4}

1 ATG GCT AAg TTT GCT TCC ATC ATC ACT CTT TTC TTC GCT ACT CTT 45

\begin{tabular}{lcccccccccccccccc}
\multicolumn{1}{c}{} & M & A & K & F & A & S & I & I & T & L & F & F & A & T & L & \\
CTT & CTC & TTT & GCT & GCT & TTT & GAA & GCA & CCA & ACA & ATG & GTG & GAA & GCT & CAG & 90
\end{tabular}

$\begin{array}{ccccccccccccccccc} & \text { L } & \text { L } & \text { F } & \text { A } & \text { A } & \text { F } & \text { E } & \text { A } & \text { P } & \text { T } & \text { M } & \text { V } & \text { E } & \text { A } & \text { Q } & \\ 91 & \text { AAG } & \text { TTG } & \text { TGT } & \text { GAG } & \text { AGA } & \text { CCA } & \text { AGT } & \text { GGA } & \text { ACA } & \text { TGG } & \text { TCA } & \text { GGT } & \text { GTT } & \text { TGT } & \text { GGT } & 135\end{array}$

$\begin{array}{ccccccccccccccccc} & \text { K } & \text { L } & \text { C } & \text { E } & \text { R } & \text { P } & \text { S } & \text { G } & \text { T } & \text { W } & \text { S } & \text { G } & \text { V } & \text { C } & \text { G } & \\ 136 & \text { AAC } & \text { AAT } & \text { GGT } & \text { GCG } & \text { TGT } & \text { AGG } & \text { AAC } & \text { CAG } & \text { TGC } & \text { ATC } & \text { AGA } & \text { CTT } & \text { GAA } & \text { AGA } & \text { GCT } & 180\end{array}$

$\begin{array}{ccccccccccccccccc} & \mathbf{N} & \mathbf{N} & \mathrm{G} & \mathbf{A} & \mathbf{C} & \mathbf{R} & \mathbf{N} & \mathbf{Q} & \mathbf{C} & \mathrm{I} & \mathbf{R} & \mathrm{L} & \mathbf{E} & \mathbf{R} & \mathbf{A} & \\ 181 & \text { CGA } & \text { CAT } & \text { GGA } & \text { TCT } & \text { TGC } & \text { AAC } & \text { TAT } & \text { GTT } & \text { TTC } & \text { CCA } & \text { GCA } & \text { CAT } & \text { AAG } & \text { TGT } & \text { ATC } & 225\end{array}$

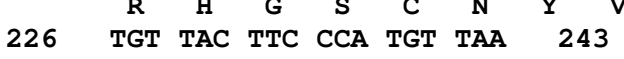

Figure 1 The cDNA sequences encoding for Hc-AFPs, isolated by PCR from cDNA generated from $H$. coronopifolia stem, leaf, flower, siliques and seed tissue. The Hc-AFP defensins are encoded within the first 240 nucleotides for Hc-AFP1and 3 and the first 243 nucleotides for HC-AFP2 and 4. The deduced amino acid sequence encoded by each gene is indicated beneath its represented sequence. 
Table 1 Peptide parameters of the newly isolated Hc-AFP defensin peptides

\begin{tabular}{lccccc}
\hline Defensin & Signal peptide (amino acids) & Mature peptide (amino acids) & MW (Da) & pl & Charge at pH7 \\
\hline HC-AFP1 & $1-29$ & $30-80$ & 5479.32 & 8.50 & 3.2 \\
\hline HC-AFP2 & $1-29$ & $30-81$ & 5718.31 & 8.73 & 4.2 \\
\hline HC-AFP3 & $1-29$ & $30-80$ & 5524.33 & 8.20 & 2.2 \\
\hline HC-AFP4 & $1-29$ & $30-81$ & 5731.61 & 8.94 & 5.2 \\
\hline
\end{tabular}

predominantly expressed in seeds and to a much lesser extent in green siliques (Figure 5B).

\section{Bacterial production and purification of Hc-AFPs}

The CBD-intein Hc-AFP fusions was successfully produced in E. coli strain BL21DE3 Rosetta gami pLysS and was visible as a $30 \mathrm{kDa}$ band on a SDS PAGE gel (result not shown). The recombinant fusion proteins were successfully purified on a chitin bead column. On-column cleavage and peptide elution was confirmed with TrisTricine SDS PAGE analysis (Figure 6). The peptides were correctly folded, displaying the expected trimeric forms $(15 \mathrm{kDa}$ bands on the Tris-Tricine gel in Figure 6) of the defensin peptides.

Mass spectrometry analysis of the purified Hc-AFPs revealed molecular masses (in Dalton) of 5471.25 for Hc-AFP1, 5710.3 for Hc-AFP2, 5516.0 for Hc-AFP3 and 5724.4 for Hc-AFP4 respectively, which correlates with their predicted mono-isotopic masses calculated with the Expasy-Compute pI/Mw tool (Table 1) (-8 Da because of oxidized cysteines). This confirmed that the purified defensins were derived from their respective genes in the bacterial expression vectors and indicated that the crucially important four disulphide bridges common to all plant defensins peptides formed.

\section{Antifungal activity of the recombinant Hc-AFP peptides}

The four plant defensin peptides from $H$. coronopifolia showed variable levels of activity against $B$. cinerea and F. solani in liquid plate assays (Table 2 and Additional File 1 and 2).

Hc-AFP2 was the most active of all the peptides tested against $B$. cinerea with $\mathrm{IC}_{50}$ values ranging between 10 $15 \mu \mathrm{g} \mathrm{ml}^{-1}$ and a similar $\mathrm{IC}_{50}$ against $F$. solani. Hc-AFP4 inhibited $B$. cinerea with an $\mathrm{IC}_{50}$ value between $15-20$ $\mu \mathrm{g} \mathrm{ml}^{-1}$, and strongly inhibited $F$. solani, having an $\mathrm{IC}_{50}$ value ranging between 5-10 $\mathrm{g} \mathrm{ml}^{-1}$ (Table 2 and Additional File 2).

Microscopical analysis conducted on $B$. cinerea hyphae treated with the four defensin peptides revealed that all the defensins induced changes in Botrytis hyphal morphology under the conditions tested. Compared to the untreated control, hyper-branching, fungal tip swelling, increased granulation of hyphae and spores, as well as hyphal and spore disruption could be observed in the cultures treated with the peptides (Table 2 Figure 7 and
Additional File 3). In addition, Hc-AFP2 and 3 had a severe effect on spore and hyphae integrity, resulting in disintegration of the hyphae and spores, which could be observed as leakage of the spore and hyphal cytoplasmic content into the surrounding environment. Moreover, assessment of propidium iodide assays revealed that the antifungal activity of all four Heliophila defensins against $B$. cinerea were associated with an increase in membrane permeabilization (Figure 7 and Additional File 3).

The peptides showed differential activity against $F$. solani (Table 2 Figure 8 and Additional File 4). HcAFP2 and 4 caused severe hyper-branching, as well as membrane permeabilization, whereas Hc-AFP1 and 3 caused mild hyper-branching and no membrane disruption against the wilting pathogen. Also, unlike the results on Botrytis, no lysis was observed in F. solani spores and hyphae when treated with the four plant defensins (Figure 8 and Additional File 4).

\section{Discussion}

Plant defensins isolated from Brassicaceae species have especially shown great promise in the fields of agricultural biotechnology and therapeutic drug design. Several of these peptides have been overexpressed in crop species leading to disease resistant traits. The overexpression of BrD1, wasabi defensin and Rs-AFP2 have led to the engineering of disease resistant rice species $[66,68,70,77]$, while the overexpression of AlfAFP1 yielded disease resistant potatoes at field trail level $[65,82]$. The overexpression of wasabi defensin in tomatoes also showed resistance towards necrotrophic pathogens [83]. Brassicaceae defensins are also used to evaluate the potential of defensin peptides in the design of new therapeutic drugs against human pathogenic yeast and fungi $[62,63,84]$. Moreover, since these defensins are well studied, they have been used as models to study the mechanisms of action of plant defensins against their target organisms [16,17,24,85-87]. Of the 449 defensin peptides listed in the protein database at the NCBI, 379 peptides belong to the Brassicaceae family.

Alignment analysis of the Brassicaceae defensin genes in the NCBI database revealed a high level of similarity $(72 \%)$ in the first $20 \mathrm{bp}$ that encode the start of the signal peptide (Additional File 5). By exploiting this 


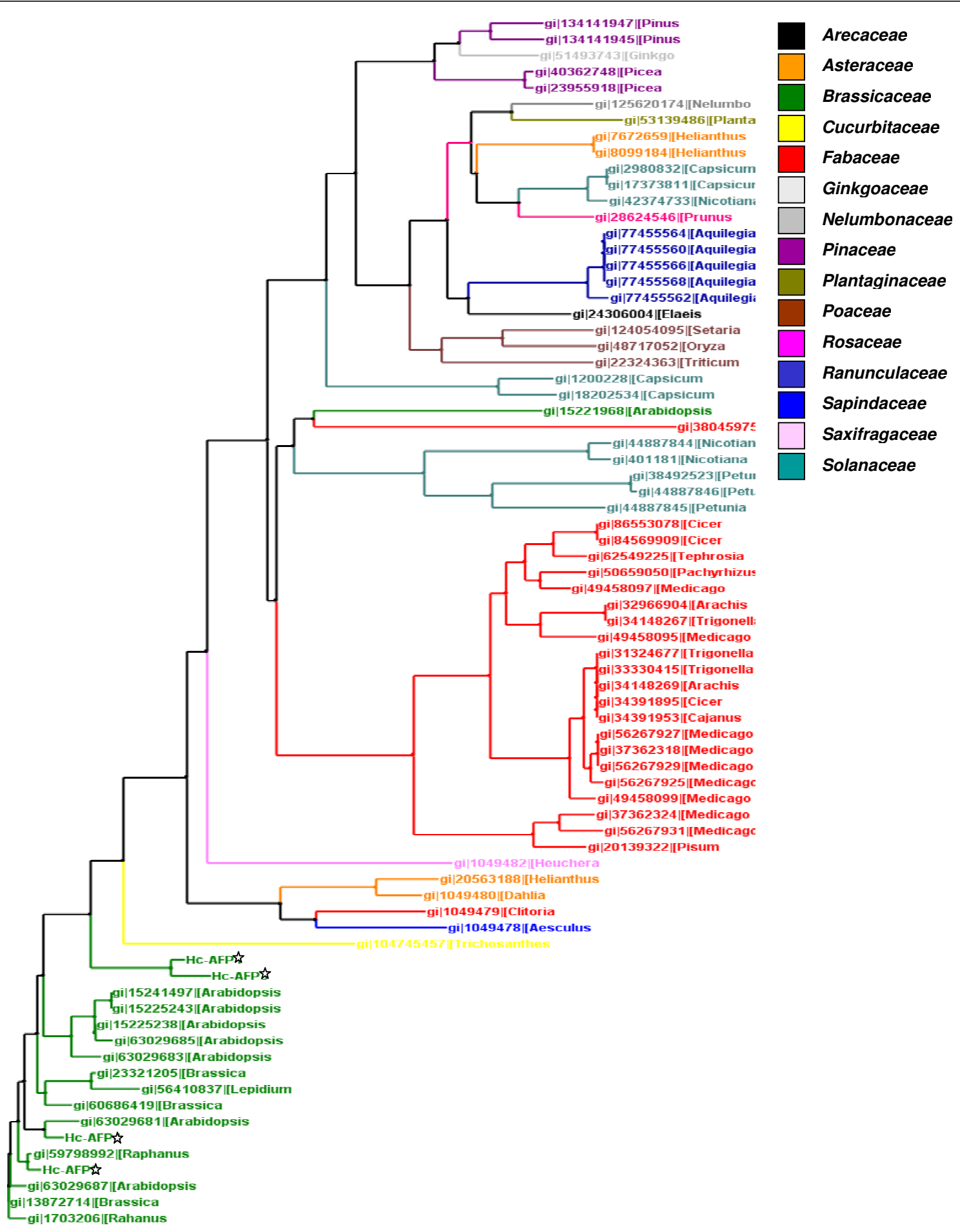

Figure 2 The phylogenetic relationship of the newly isolated Hc-AFPs with members of the plant defensin super family. The deduced amino acid sequences of the newly isolated defensins (indicated with *) were aligned in ClustalX with other members of the defensin super family isolated from various plant genera. The tree was created in Arbodraw. The newly isolated defensins showed the closest relation to defensin peptides isolated from other Brassicaceae species. 


\begin{tabular}{|c|c|c|}
\hline & & $\begin{array}{c}\begin{array}{c}\% \text { Similarity } \\
\text { to }\end{array} \\
\text { Hc-AFP1 }\end{array}$ \\
\hline & 51 & \\
\hline gi_11386628 Rs-AFP3 & -KLCERSSGTWSGVCGNNNACKNQCIRLEGAQHGSCNYVFPAHKCICYFPC & 82 \\
\hline gi_11386640 Bn-AFP3 & -KLCERSSGTWSGVCGNNNACKNQC IRLEGAQHGSCNYVFPAHKC ICYFPC & 82 \\
\hline gi_23321205 Br-AFP & QKLCERSSGTWSGVCGNNNACKNQC INLEGARHGSCNYVFPYHRCICYFPC & 74 \\
\hline gi_310697404 Br-AFP1.2 & -KLCERS SGTWSGVCGNNNACKNQC INLEGARHGSCNYVFPYHRCICYFPC & 76 \\
\hline gi_281486468 Br insectR & QKLCERSSGTWSGVCGNNNACKNQC INLEGARHGSCNYVFPYHRCICYFPC & 74 \\
\hline gi_11386627 Rs-AFP4 & QKLCERSSGTWSGVCGNNNACKNQC INLEGARHGSCNYIFPYHRCICYFPC & 72 \\
\hline gi_59798992Rs-AFP1 & QKLCERPSGTWSGVCGNNNACKNQCINLEKARHGSCNYVFPAHKCICYFPC & 74 \\
\hline $\mathrm{gi}^{-} 81176559 \mathrm{Bj}-\mathrm{AFP}$ & QKLCERPSGTWSGVCGNNNACKNQC INLEKARHGSCNYVFPAHKCICYFPC & 74 \\
\hline gi-1703204 Sa-AFP1 & QKLCERPSGTWSGVCGNNNACKNQC INLEKARHGSCNYVFPAHKCICYFPC & 74 \\
\hline gi_13872714 Bo-AFP & QKLCERPSGTWSGVCGNNNACKNQCIRLEKARHGSCNYVFPAHKCICYFPC & 76 \\
\hline gi_63029687 PDF1.4 & QKLCERASGTWSGVCGNNNACKNQC IRLEKARHGSCNYVFPAHKCICYFPC & 76 \\
\hline gi_1703192 Sa-AFP2a & QKLCQRPSGTWSGVCGNNNACRNQC INLEKARHGSCNYVFPAHKCICYFPC & 72 \\
\hline gi_242724021 Ov-AFP & QKLCQRPSGTWSGVCGNNNACKNQC INLEKARHGSCNYVFPAHKCICYFPC & 72 \\
\hline gi_1703206 Rs-AFP2 & QKLCQRPSGTWSGVCGNNNACKNQCIRLEKARHGSCNYVFPAHKCICYFPC & 74 \\
\hline gi_63029681 PDF1.1 & QRLCEKPSGTWSGVCGNNGACRNQC IRLEKARHGSCNYVFPAHKCICYFPC & 78 \\
\hline $\mathrm{HC}-\mathrm{AFP} 4$ & QKLCERPSGTWSGVCGNNGACRNQC IRLERARHGSCNYVFPAHKCICYFPC & 78 \\
\hline $\mathrm{HC}-\mathrm{AFP} 2$ & QKLCERPSGTWSGVCGNNNACRNQC INLEKARHGSCNYVFPAHKC ICYFPC & 74 \\
\hline gi_297839465 Al-AFP & QKLCEKPSGTWSGVCGNSGACKNQC INLEGARHGSCNYVFPAHKCICYFPC & 78 \\
\hline gi_63029683 PDF1.2 & QRLCEKPSGTWSGVCGNSGACKNQC INLEGARHGSCNYVFPAHKCICYFPC & 80 \\
\hline $\mathrm{gi}^{-} 62823009 \mathrm{Sa}-\mathrm{AFP}$ & QKLCERPSGTWSGVCGNSNSCKNQC INLEGARHGSCNYVFPAHKCICYFPC & 78 \\
\hline $\mathrm{HC}-\mathrm{AFP} 1$ & -RYCERS SGTWSGVCGNSGKCSNQCQRLEGAAHGSCNYVFPAHKCICYYPC & 100 \\
\hline $\mathrm{HC}-\mathrm{AFP} 3$ & -RYCERSSGTWSGVCGNTDKCSSQCQRLEGAAHGSCNYVFPAHKCICYYPC & 94 \\
\hline gi 15225243 Def-like 15 & QKLCEKPSGTWSGVCGNSNACKNQC INLEGAKHGSCNYVFPAHKCICYVPC & 76 \\
\hline gi 15241496 Def-like 16 & QKLCEKPSGTWSGVCGNSNACKNQC INLEGAKHGSCNYVFPAHKCICYVPC & 76 \\
\hline gi_15225238Def-like 14 & QKLCEKPSGTWSGVCGNSNACKNQC INLEGAKHGSCNYVFPAHKCICYFPC & 76 \\
\hline gi_63029685 PDF1.3 & QKFCEKPSGTWSGVCGNSNACKNQC INLEGAKHGSCNYVFPAHKCICYFPC & 76 \\
\hline Consensus & QKLCERPSGTWSGVCGNNNACKNQC INLEGARHGSCNYVFPAHKCICYFPC & \\
\hline & \begin{tabular}{l|l} 
\\
\end{tabular} & \\
\hline
\end{tabular}

Figure 3 Alignment of the mature region of the Hc-AFP peptides with members of the plant defensin family isolated from Brassicaceae species. The percentage similarity compared to Hc-AFP1 is indicated in the last column. Arabidopsis halleri: [GenBank 63029681, 63029683, 63029685, 63029687]; Arabidopsis lyrata: [GenBank 297839465]; Arabidopsis thaliana: [GenBank 18410943, 15225243, 15241496, 15225238]; Brassica napus: [GenBank 11386640]; Brassica juncea: [GenBank 81176559]; Brassica oleracea: [Genbank 13872714]; Brassica rapa: [GenBank 23321205, 310697404, 281486468]; Orychophragmus violaceus: [GenBank 242724021]; Raphanus sativa: [GenBank 59798992, 1703206, 1138662811386627]; Sinapsis alba: [GenBank 1703192, 170320462823009]. The disulphide bridge pattern, common to all plant defensins, is indicated in red.

homology, a PCR-based isolation strategy was used to amplify putative defensins from pools of cDNA made from the various tissue types of $H$. coronopifolia, a native South African Brassicaceae species currently unexplored for novel antimicrobial peptides. Four plant defensin peptide encoding genes, termed $H c-A F P 1$ to 4 (Figure 1) were obtained and analysis of the deduced amino acid sequences revealed that the newly isolated peptide encoding genes shared the common structural design of other Brassicaceae defensins. Alignment analysis of the mature region showed that the Hc-AFP peptides shared $72 \%$ similarity at deduced amino acid level (Figure 3), and were more closely related to the defensins isolated from Brassicaceae species than from other plant species (Figure 2). Hc-AFP1 and 3 grouped closely together and displays amino acid sequences in the $\alpha$ helix area unique to peptides in the Brassicaceae family.
The homology models of the Hc-AFP peptides (Figure 4) revealed important differences between the different Hc-AFPs. Most of the amino acid differences occurred in the $\alpha$-helical region, forming two structurally defined groups, with Hc-AFP1 and 3 in the first group and HcAFP2 and 4 in the second group. Despite the amino acid differences occurring in the $\alpha$-helical region a large deviation were observed $(1.7 \AA)$ in the $L \beta_{2} \beta_{3}$ loop when the structures were superimposed (Figure 5G). Hc-AFP2 and 4 shares high homology to Rs-AFP2 and the $\mathrm{L} \beta_{2} \beta_{3}$ loop of Rs-AFP2 have been well studied over the past years and have been linked to the antifungal activity of this peptide $[16,86,87]$. It was shown that the sequence ARHGSCNYVFPAHKCICYF is important for antifungal activity, especially the basic Arg32 residue and Tyr48 (numbering according to Rs-AFP2) [86]. This sequence is also present in the Hc-AFPs, but in Hc-AFP1 and 3 


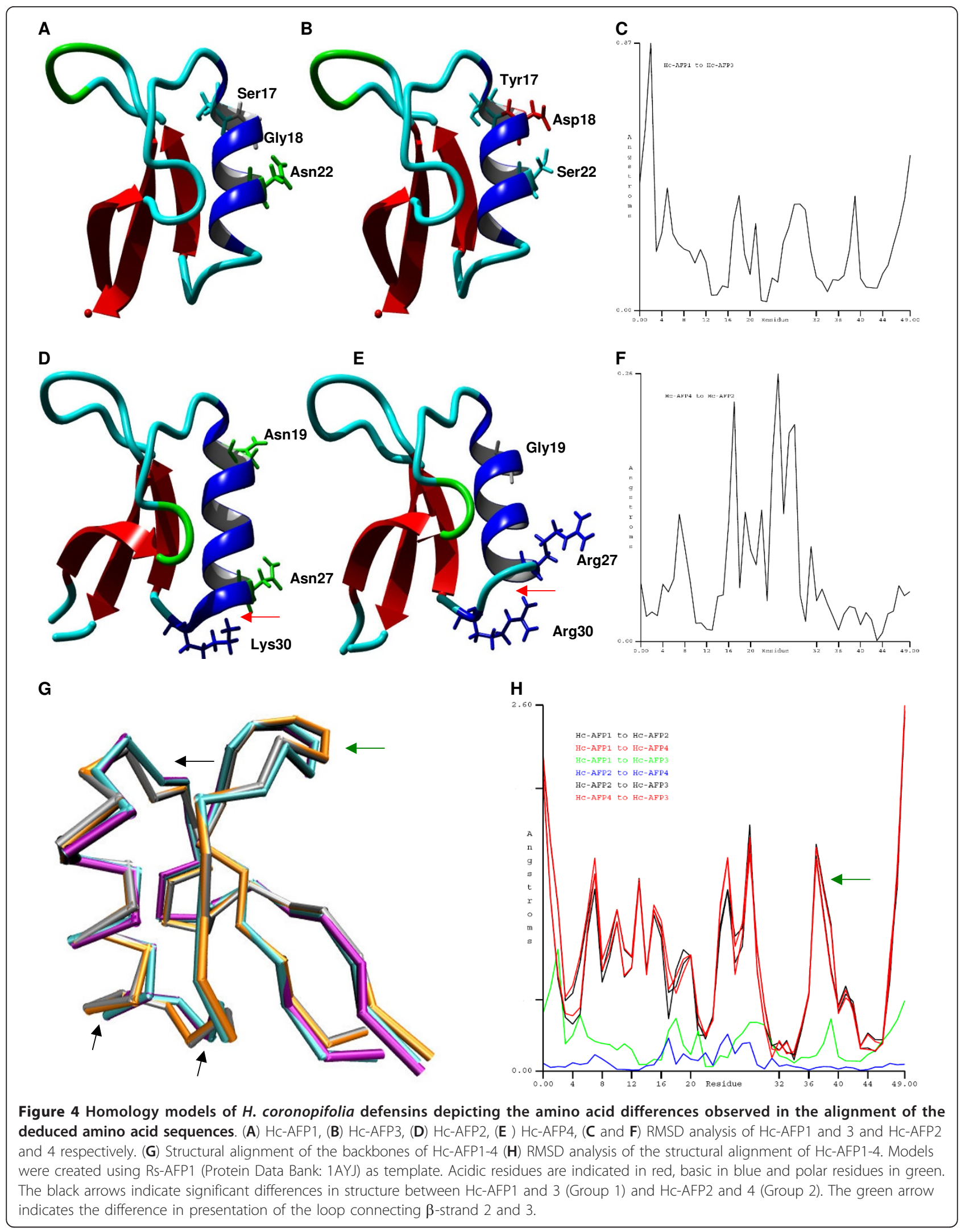




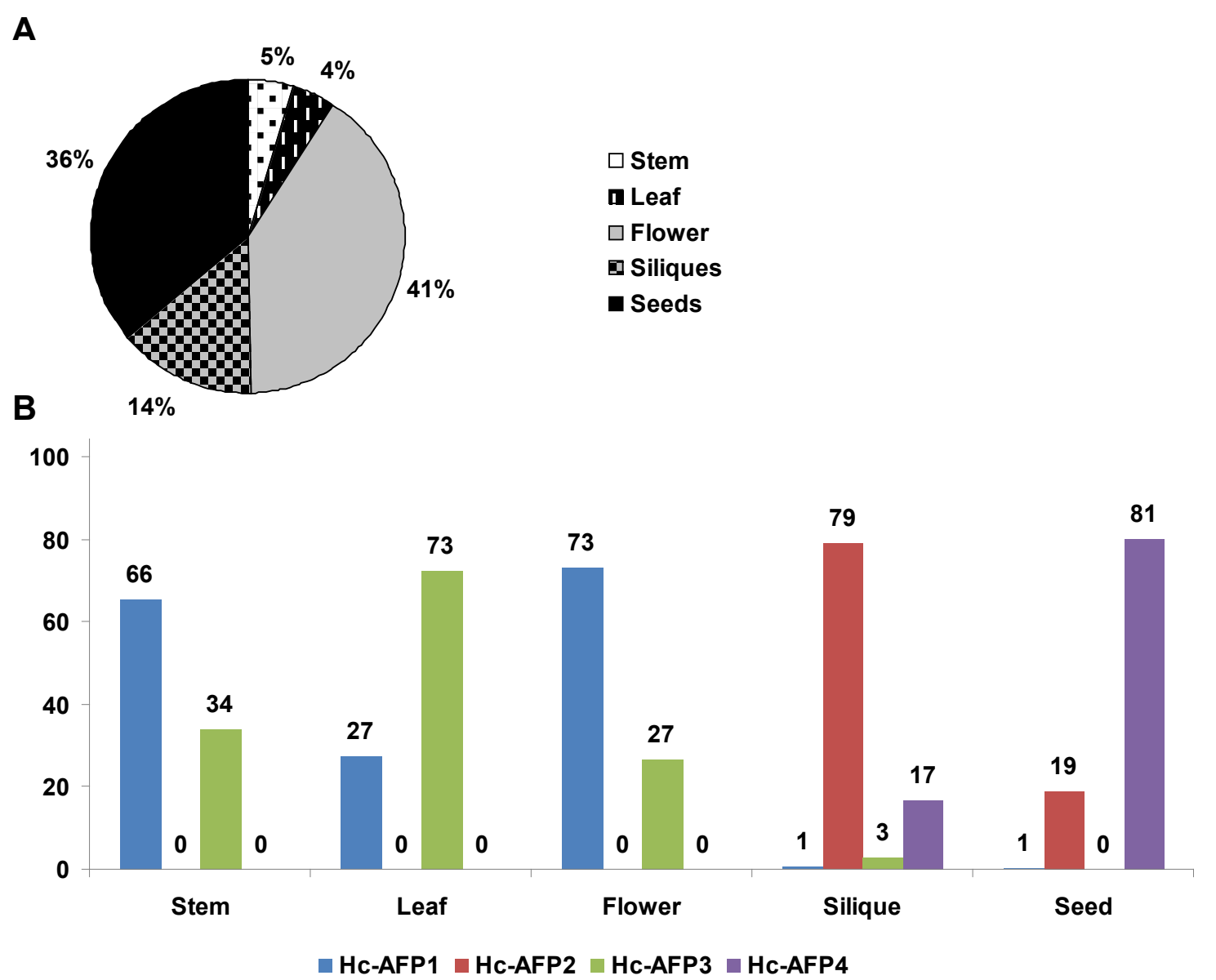

Figure 5 The expression profile of the newly isolated defensin genes in the different tissue types of $H$. coronopifolia as determined with q-RT-PCR. Data was analyzed using the software package LinRegPCR ver 11.0 and are expressed as an percentage of the total defensin transcript present at the moment of cDNA synthesis.

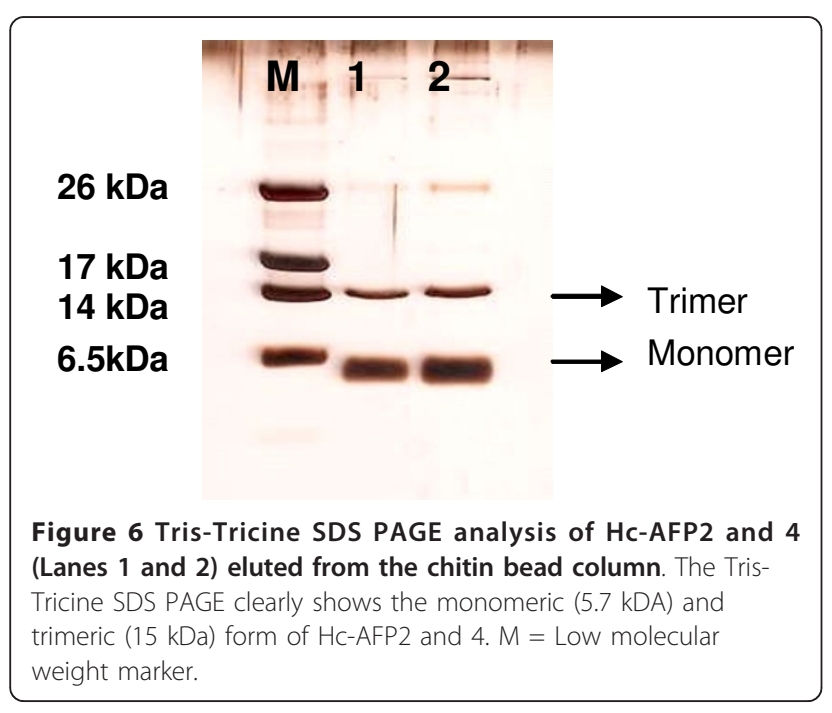

the important Arg32 is replaced by Ala, resulting in a less basic loop for Hc-AFP1 and 3 (charge at $\mathrm{pH} 7$ : +1.176 ) compared to Hc-AFP2 and 4 (charge at $\mathrm{pH} 7$ : +2.176 ). Recently it was shown that the overall charge of the $\mathrm{L} \beta_{2} \beta_{3}$ loop (also termed the $\gamma$-core) is a determinant for the differential activities observed between closely related plant defensin peptides and might explain the differential antifungal activity observed between the Hc-AFP defensins [88]. The $\mathrm{L}_{2} \beta_{3}$ loop has also been connected with other biological activities associated with plant defensins, including anti insecticidal activity and enzyme inhibition $[36,78]$. The $L \beta_{2} \beta_{3}$ loop is not the only area of the peptide structure that plays a role in antifungal activity and recently a role for the loop connecting the $\alpha$-helix and first $\beta$-strand have been proposed for the interaction of plant defensins with their fungal target $[89,90]$, an area where the Hc-AFPs show high sequence divergence and a deviation of $1.6 \AA$ when the structures are superimposed (Figure 5G and 5H). 
Table 2 Antifungal activity of the Heliophila coronopifolia defensins

\begin{tabular}{|c|c|c|c|c|c|c|c|c|}
\hline \multirow[b]{2}{*}{ Defensin } & \multicolumn{4}{|c|}{ Botrytis cinerea } & \multicolumn{4}{|c|}{ Fusarium solani } \\
\hline & $\begin{array}{r}\mathrm{IC}_{50} \\
\mu \mathrm{g} \mathrm{m}^{-1}\end{array}$ & Hyphal morphology & Spore lysis & $\mathrm{MP}^{\mathrm{a}}$ & $\begin{array}{c}\mathrm{IC}_{50} \\
\mu \mathrm{g} \mathrm{m \textrm { } \mathrm { I } ^ { - 1 }}\end{array}$ & Hyphal morphology & Spore lysis & $M P^{a}$ \\
\hline Hc-AFP1 & $>25$ & Tip swelling & No & Yes & $>25$ & Mild hyper-branching & No & No \\
\hline Hc-AFP2 & $10-15$ & $\begin{array}{c}\text { Severe hyper-branching } \\
\text { Tip swelling } \\
\text { Lysis }\end{array}$ & Yes & Yes & $10-15$ & Severe hyper-branching & No & Yes \\
\hline Hc-AFP3 & $20-25$ & $\begin{array}{l}\text { Severe hyper-branching } \\
\text { Tip swelling and disruption }\end{array}$ & Yes & Yes & $>25$ & Mild hyper-branching & No & No \\
\hline Hc-AFP4 & $15-20$ & $\begin{array}{l}\text { Mild hyper-branching } \\
\text { Tip swelling }\end{array}$ & No & Yes & $5-10$ & Severe hyper-branching & No & Yes \\
\hline
\end{tabular}

${ }^{\mathrm{a}} \mathrm{MP}=$ Membrane permeabilization

\section{Expression profiling of the Hc-AFP genes}

The differential and tissue-specific expression pattern of the Heliophila defensins proposes different roles for the four defensins. The expression of $H c-A F P 1$ and 3 in the vegetative and floral tissues propose a role in the protection against fungal infection of these tissues. The significant contribution of $H c-A F P 1$ to the total pool of defensin transcripts present in the $H$. coronopifolia flowers might suggest a key role for Hc-AFP1 in the protection of the reproductive structure against pathogens. The very lytic activity of the peptides against Botrytis spores and hyphae might support this notion, since this necrotrophic pathogen typically attack vegetative and floral structures. Similarly, the strong activity against the wilting pathogen of the Hc-AFP2 and 4 peptides and their exclusive expression in the storage organs of the plant suggests that these peptides could be instrumental in protecting the germinating seeds against soil-borne pathogens such as F. solani. Moreover, the expression of the majority of Heliophila defensin transcript in the reproductive and storage organs is not unexpected, since the majority of isolated and characterized plant defensin peptides have been isolated from these organs [42,47-51,64,73,91-94], highlighting the importance of plant defensins in the protection of the reproductive systems of plants. This is especially well documented for the radish defensins Rs-AFP1 and 2, to which the Heliophila defensins share high homology. It has been shown that the radish defensins form preformed barriers within these tissues to stop the initiation or spread of fungal infection [42]. The tissue-specific expression of Hc-AFP2 and 4 also propose a role in the protection of seeds against fungal attack as well as a possible role in protection during seed germination as has been observed for the radish defensins Rs-AFP1 and 2, which share 94\% and $98 \%$ similarity to Hc-AFP2 and 4, respectively.

The differential expression pattern might, however, also indicate that the various peptides could play roles in the developmental and/or physiological processes of these organs and tissues, as was observed for some defensins isolated from maize and tomato [50,57]. These aspects need to be further evaluated with in vivo analysis.

\section{Recombinant production and purification}

The high level of codon bias and the inability of $E$. coli to form disulphide bridges, solubility issues and affinity tag removal have made the production of plant defensins in bacteria notoriously difficult. By utilizing a codon-optimized E. coli strain with the ability to form disulphide bridges, we were able to successfully produce all four peptides in a soluble state.

The expression and purification strategy resulted in the purification (to homogeneity) of each peptide in a single chromatographic step. Disulphide bridge formation could also be confirmed by LC-MS analysis.

\section{Antifungal activity of the Hc-AFP peptides}

Plant defensin peptides can be divided into three groups based on their antifungal activity. The first group known as morphogenic defensins are highly active against fungal pathogens and induce morphological changes in treated hyphae which results in severe hyper-branching of the fungal hyphae $[14,21,71,95]$. Most plant defensins isolated from Brassicaceae species belong to this group. The second group inhibits fungal pathogens, but do not induce morphological changes and are known as nonmorphogenic defensins, with the third group not exhibiting any antifungal activity.

The peptides from $H$. coronopifolia were classified as morphogenic defensins since they had severe effects on hyphal development and morphology under the conditions tested. Recombinant Hc-AFP1 to 4 showed strong antifungal activity, also confirming the correct folding of the peptides during bacterial production. The peptides were tested against two agronomically important pathogens namely $B$. cinerea, the most destructive necrotrophic pathogen with a wide host range and the wilting disease agent F. solani. With the exception of Hc-AFP1, the Hc-AFPs showed strong activity against $B$. cinerea 


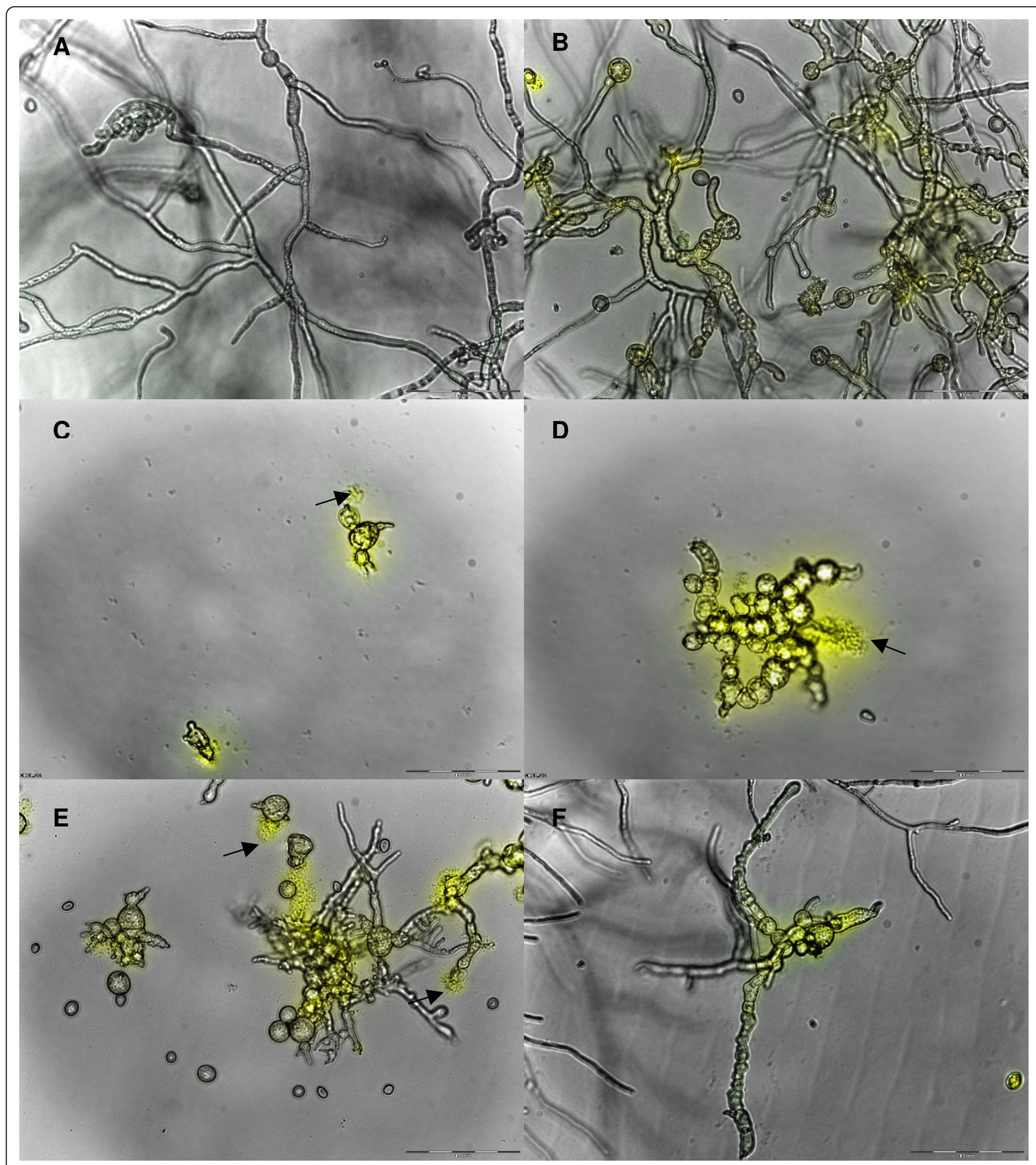

Figure 7 Combined overlay of the light microscopical analysis at 20x magnification and the cell permeabilization assay conducted on B. cinerea grown in the presence of Hc-AFPs for $\mathbf{4 8} \mathbf{~ h}$ at $23^{\circ} \mathbf{C}$. (A) Control, (B) Hc-AFP1 $25 \mathrm{~g} \mathrm{ml}^{-1}$, (C and D) Hc-AFP2 $15 \mu \mathrm{g} \mathrm{ml} \mathrm{l}^{-1}$, (E) HcAFP3 $25 \mathrm{~g} \mathrm{ml}^{-1}$, (F) Hc-AFP4 $18 \mathrm{mg} \mathrm{ml}^{-1}$. The yellow fluorescence indicates a compromised membrane and the black arrows indicate structures that are leaking their cellular content into the surrounding medium. 


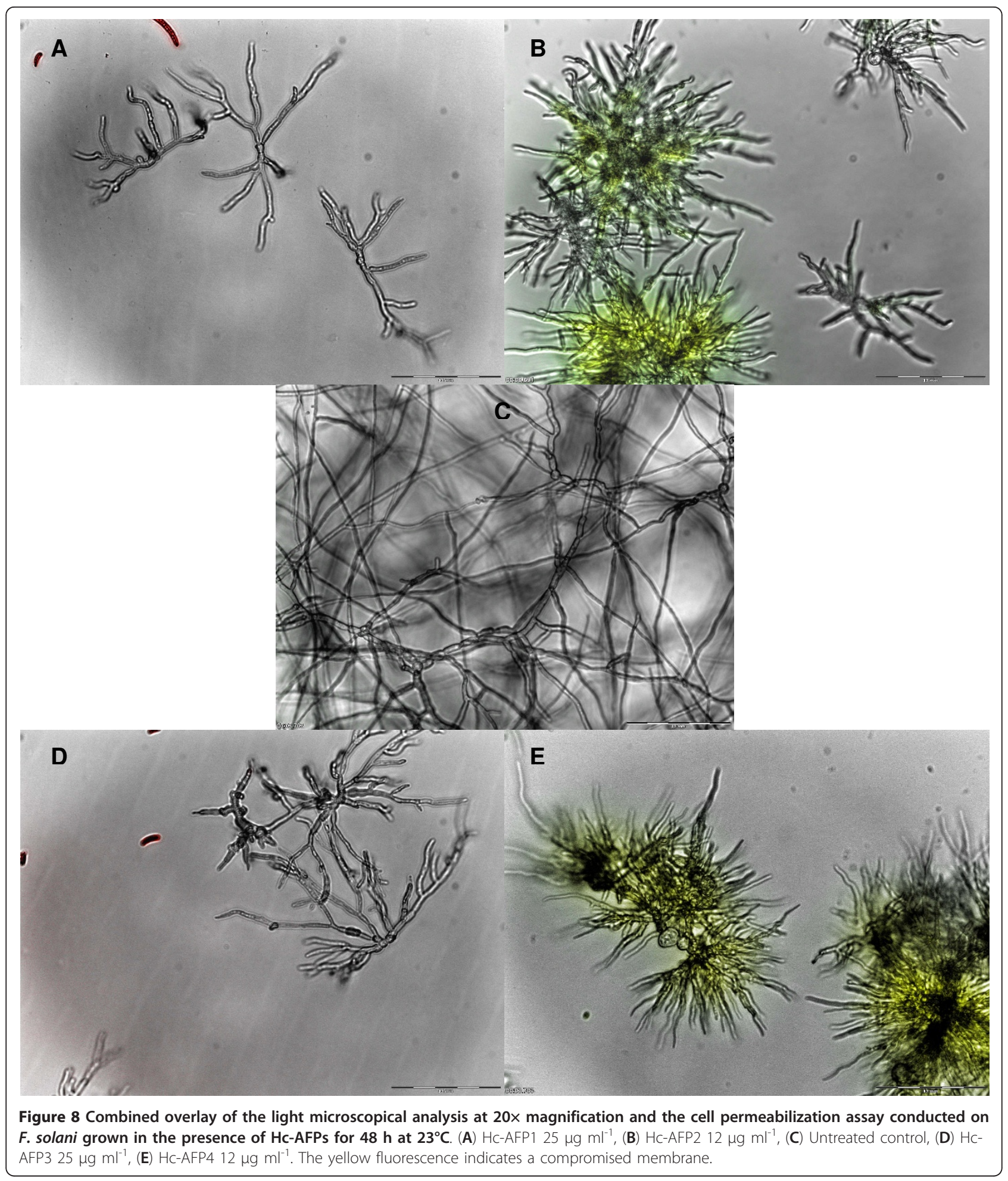

with $\mathrm{IC}_{50}$ values below $25 \mu \mathrm{g} \mathrm{ml}^{-1}$. All three peptides, with the exception of Hc-AFP1, induced a severe hyperbranching effect in treated hyphae, a common characteristic of defensins isolated from Brassicaceae species. The activity exerted by the Hc-AFPs against $B$. cinerea was also linked to membrane permeabilization, similar to what was observed for Rs-AFP2, a defensin from radish against fungal pathogens [96]. Hc-AFP2 and 3 had a severe effect on the integrity of Botrytis hyphae and spores, resulting in the disintegration of the fungal 
membrane and leakage of the cytoplasmic content into the surrounding environment. This lytic activity has not previously been described for Brassicaceae defensins according to our knowledge. The differential activity against F. solani, where Hc-AFP1 and 3 show reduced activity compared to Hc-AFP2 and 4, correlates well with their expression patterns. F. solani is a soil pathogen and Hc-AFP2 and 4, which show expression only in the storage organs, shows strong activity against this pathogen, strengthening the proposed role for these peptides during seed germination and seedling protection against soil borne pathogens. The expression of Hc-AFP1 and 3 in the vegetative tissues might also explain why they show more activity against pathogens evolved to infect vegetative tissues like the necrotrophic pathogen $B$. cinerea.

The effects on Botrytis (positive membrane disruption, severe morphological effects and even lytic activity) suggest that the activities could be orchestrated with the membrane being the primary target. However, recent evidence suggests that the cell wall also might play a role in membrane permeabilization [67] and that the membrane might actually be the secondary target. Interestingly, the Fusarium data indicated that Hc-AFP1 and 3 did not affect the membranes of the pathogen, since no membrane permeabilization was observed. These divergent activities of the Heliophilia peptides should be studied further. Future work will focus on exploring the structure-function relationships in the four peptides, and the implications on activity, specifically since these four peptides are highly homologous on amino acid sequence level, but display a few pointed changes in certain important defensin motifs which might be underpinning the observed variation in activities and mode-of action.

\section{Conclusions}

The homology that resides within the signal peptides of plant defensins belonging to the same plant family is significant and allowed us to successfully implement a PCR-based method to isolate four Brassicaceae defensins. This strategy might be useful to isolate new defensin sequences from unsequenced plants species belonging to the same plant family. Despite the high level of homology on sequence level that was observed for the peptides, they were predicted to differ in their structural and surface properties, aspects that are known to influence activity levels and range. These aspects, as well as their observed divergent expression patterns, activities and modes of action against two test pathogens, provide interest to explore the structure-activity relationship of these peptides further.

\section{Methods}

\section{Microbial strains and plant material}

Escherichia coli strain DH5 $\alpha$ were used for all cloning experiments, while E. coli strain BL21 Rosetta-gami pLysS DE3 (Novagen, Madison, WI, USA) were used for recombinant protein production. Fusarium solani and Botrytis cinerea cultures were obtained from the Department of Plant Pathology (DPP), Stellenbosch University and maintained on potato dextrose agar at $25^{\circ} \mathrm{C}$ until sporulation. Spores were harvested in $\mathrm{dH}_{2} \mathrm{O}$ and spore concentrations determined using a haemocytometer. Heliophila coronopifolia seeds were obtained from Silverhill seed company, South Africa. $H$. coronopifolia plants were established in potting soil from seeds and maintained under green-house conditions at $25^{\circ} \mathrm{C}$.

\section{Design of Primer SPDEF-5'}

The design of primer SPDEF-5 is based on the high level of homology that exists within the nucleotide sequences encoding for the signal peptides of plant defensin peptides belonging to the plant family Brassicaceae. Plant defensin encoding sequences isolated from Brassicaceae species was identified in the Genbank database of the National Centre for Biotechnological information (NCBI). The first 50 nucleotides encoding for the $\mathrm{N}$-terminal signal peptide of the Brassicaceae plant defensin peptides were selected and aligned in AlignX (Invitrogen, Carlsbad, USA) (Additional File 5). 72\% similarity existed over the first 50 amino acids. The consensus sequence were identified and the first 20 nucleotides were used to design primer SPDEF-5' (5'ATGGCTAAGTTTGCTTCCATCAT-3’).

\section{RNA isolation and CDNA synthesis}

Total RNA was isolated from stem, leaf, flower, green siliques and mature seeds of $H$. coronopifolia. The tissue was ground to a fine powder in the presence of liquid nitrogen and total RNA was extracted from $200 \mathrm{mg}$ powdered tissue according to Chang et al [97]. Total RNA was precipitated with $3 \mathrm{M} \mathrm{LiCl}$ and washed with $70 \%(\mathrm{v} / \mathrm{v})$ ethanol and dissolved in $26 \mu \mathrm{l}$ RNase free water. The samples were treated with DNaseI (Roche Diagnostics GmbH, Mannheim, Germany) to remove genomic DNA contamination in a $30 \mu$ reaction. Sample volumes was adjusted to $200 \mu \mathrm{l}$ with RNase free water and the DNaseI removed by extracting with an equal volume phenol/chloroform $(50: 50 \mathrm{v} / \mathrm{v})$, followed by an equal volume chloroform to remove the phenol. The RNA was precipitated with a $1 / 10$ volume $3 \mathrm{M}$ $\mathrm{NaOAc}$ and 0.7 volumes isopropanol, washed with $70 \%$ (v/v) ethanol and dissolved in RNase free water. First strand cDNA was synthesized from $1 \mu \mathrm{g}$ of total RNA 
using an anchored oligo $\mathrm{dT}_{23}$ primer (Sigma, St Louis, USA) and Superscript III (Invitrogen, Carlsbad, USA). cDNA synthesis was performed as described by the manufacturer.

\section{Gene isolation and cloning}

The coding regions of potential plant defensin sequences were PCR amplified from total stem, leaf, flower, silique and seed cDNA using primer set SPDEF5 ' and the anchored oligo $\mathrm{dT}_{23}$ primer (Sigma, St Louis, USA) used for cDNA synthesis. The PCR reaction was performed in a $50 \mu \mathrm{l}$ reaction containing: $1 \times$ Expand buffer with $1.5 \mathrm{mM} \mathrm{MgCl} 2,0.2 \mathrm{mM}$ dNTPs, $200 \mathrm{nM}$ SPDEF-5' primer, $200 \mathrm{nM}$ oligo $\mathrm{dT}_{23}, 10 \mathrm{ng}$ template DNA and $1 \mathrm{U}$ Expand high fidelity polymerase (Roche Diagnostics GmbH, Mannheim, Germany). The PCR program was as follows: $95^{\circ} \mathrm{C}$ for $5 \mathrm{~min}$; followed by 30 cycles of $95^{\circ} \mathrm{C}$ for $45 \mathrm{sec}, 48^{\circ} \mathrm{C}$ for $30 \mathrm{sec}$ and $72^{\circ} \mathrm{C}$ for $45 \mathrm{sec}$. PCR products were cloned into pGEM-T easy vector (Promega Corporation, Madison, USA) and positive clones were identified through restriction digest with EcoRI. Plasmids containing inserts were confirmed by sequencing. Obtained sequences were analyzed with the BLASTN algorithm http://blast.ncbi.nlm.nih.gov/ Blast.cgi at the NCBI and clones containing open reading frames encoding for plant defensins were identified and termed pGEM-Hc1-4. The sequences were deposited to Genbank with the following accession numbers: JN203136 (Hc-AFP1), JN203137 (Hc-AFP2), JN203138 (Hc-AFP3) and JN203139 (Hc-AFP4).

\section{Bioinformatical analysis of the four $\mathrm{H}$. coronopifolia defensin sequences}

The deduced amino acid sequences of Hc-AFP1-4 was created in BioEdit [98] and analyzed with the ExpasyCompute pI/Mw tool http://web.expasy.org/compute_pi/ to obtain the different peptide parameters and Biochemistry online http://vitalonic.narod.ru/biochem to determine the overall charge of the peptides and their $L \beta_{2} \beta_{3^{-}}$ loops. The peptide structure of each peptide was evaluated for the presence of a signal peptide sequence with SignalP http://www.cbs.dtu.dk/services/SignalP/ and the possible disulphide bridge pattern for each peptide was determined using the web services DIpro http://download.igb.uci.edu/bridge.html.

The deduced amino acid sequences encoding for the mature plant defensin peptides were aligned against a diverse set of mature plant defensin sequences isolated from various plant genera. All sequences were obtained from the NCBI and alignment with the newly isolated defensins was performed in ClustalX [99]. A graphical representation of the phylogenetic tree was created in Arbodraw [100].
Homology models for each Hc-AFP peptide was created with the Bioinformatics toolkit at the Max Planck Institute for developmental biology http://toolkit.tuebingen.mpg.de/. The crystal structure of Rs-AFP1 (Protein Data Bank: 1AYJ) from radish was used as template. The models obtained were refined and analyzed with YASARA structure [101,102] and the FoldX plugin [103]. Models were visualized in Visual Molecular Dynamics ver 1.8.4 and the final images rendered with POV-Ray.

\section{q-RT-PCR analysis of the Hc-AFP encoding genes}

Analysis was conducted on each of the newly isolated genes using the primer sets listed in Table 3. Each primer set was optimized to determine the optimal ratio of the forward and reverse primer in the primer set. The PCR efficiency was determined by setting up a standard curve prepared from the cDNA used to isolate the respective genes. The standard curve consisted of a $1 / 4$ to $1 / 1024$ dilution of the respective cDNA template. qRT-PCR reactions with different ratios of forward and reverse primers were performed with the KAPA SYBR FAST qPCR Kit (Kapa Biosystems, South Africa) in a 20 $\mu \mathrm{l}$ reaction. All q-RT-PCR analysis were performed on a ABI7500 Real-Time PCR System (Applied Biosystems, South Africa) with the following program: $95^{\circ} \mathrm{C}$ for 5 min followed by 40 cycles of $95^{\circ} \mathrm{C}, 15 \mathrm{sec} ; 60^{\circ} \mathrm{C}, 32 \mathrm{sec}$. The 40 cycles was followed by a dissociation curve consisting of a ramp from $95^{\circ} \mathrm{C}$ to $60^{\circ} \mathrm{C}$. The $\mathrm{Ct}$ values obtained were used as input data in the REST2009 software package [104] to calculate the PCR efficiency of each primer set. The optimized q-RT-PCR primer ratios were used to evaluate the expression of $H c-A F P 1-4$ in the different $H$. coronopifolia tissue types. The q-RTPCR reactions were done as described above with each reaction containing the optimized primer concentration listed in Table 3. The data obtained were analyzed in LinRegPCR v11.0 software package [105] to determine the transcript levels for each gene present at the time of cDNA synthesis in the various tissue types. Elongation factor alpha $(E F \alpha)$ was used to standardize the expression levels obtained between the different tissues. The data for the individual genes are expressed as a percentage of the total defensin transcript present in the tissue.

\section{Recombinant production of Hc-AFPs in E. coli}

Hc-AFPs were produced in $E$. coli by using the IMPACT system (New England Biolabs, Ipswich, MA, USA). The DNA regions encoding for mature Hc-AFPs was cloned into the pTWIN1 vector, which allows for expression under control of the IPTG inducible T7 promoter. The cloning strategy allowed for a fusion between the Hc-AFPs and a chitin binding domain 
Table 3 Primers used in the q-RT-PCR analysis of the Hc-AFP defensin genes

\begin{tabular}{lllll}
\hline Primer set & Sequence $\mathbf{5}^{\prime} \rightarrow \mathbf{3}^{\prime}$ & Primer & Target gene & PCR eff. \\
\hline Helio EF Fw & ATGGGTAAAGAGAAGTTTCACATCAA & $150 \mathrm{~nm}$ & H. coronopifolia elongation factor $1 \boldsymbol{\alpha}$ & 0.99 \\
Helio EF Rv & GTTGGGTCCTTCTTGTCAACACTC & $200 \mathrm{~nm}$ & & \\
\hline Hc-AFP1 Rt Fw & TCAGGAGTTTGTGGAAACAGTGG & $200 \mathrm{~nm}$ & Hc-AFP1 & 0.98 \\
Hc-AFP1 Rt Rv & GCAGCCAACATAAACATATTTTGGA & $150 \mathrm{~nm}$ & & 0.99 \\
\hline Hc-AFP2 Rt Fw & CGTGTAGGAACCAGTGCATCAAC & $150 \mathrm{~nm}$ & Hc-AFP2 \\
Hc-AFP2 Rt Rv & TAGGATTTTTCTGGTATGGCCG & $200 \mathrm{~nm}$ & \\
\hline Hc-AFP3 Rt Fw & TCAGGAGTTTGTGGAAACACTGA & $150 \mathrm{~nm}$ & Hc-AFP3 & 0.97 \\
Hc-AFP3 Rt Rv & ATCATTAGAAGCTGCCAACATAAACTAG & $200 \mathrm{~nm}$ & & \\
\hline Hc-AFP4 Rt Fw & ATGGTGGAAGCTCAGAAGTTGTGT & $200 \mathrm{~nm}$ & Hc-AFP4 & 0.92 \\
Hc-AFP4 Rt Rv & GCTAGCAGCAAAGATGTTTGTTTG & $150 \mathrm{~nm}$ & & \\
\hline
\end{tabular}

(CBD) to facilitate downstream purification using affinity chromatography. In the pTWIN system the HcAFPs and the CBD are separated by an intein peptide sequence that under goes self cleavage upon induction by $\mathrm{pH}$ and temperature shift.

The mature coding sequence of Hc-AFP1 to 4 was PCR amplified from pGEM-Hc1 to 4 using the primer sets listed in Additional File 6.

PCR reactions were performed in a $50 \mu \mathrm{l}$ reaction volume containing: $1 \mathrm{x}$ Expand buffer with $1.5 \mathrm{mM}$ $\mathrm{MgCl}_{2}, 0.2 \mathrm{mM}$ dNTPs, $200 \mathrm{~nm}$ Forward and Reverse primer, $1 \mathrm{ng}$ template DNA and $1 \mathrm{U}$ Expand high fidelity polymerase. The mature coding regions were PCR amplified using the following program, $95^{\circ} \mathrm{C}$ for $5 \mathrm{~min}$; followed by 30 cycles of $95^{\circ} \mathrm{C}$ for $45 \mathrm{sec}, 55^{\circ} \mathrm{C}$ for $30 \mathrm{sec}$ and $72^{\circ} \mathrm{C}$ for $45 \mathrm{sec}$. PCR products were cloned into pGEM-T easy and positive clones were identified through digestion with EcoRI. Positive clones were termed pGEM-Hc1-Impact, pGEM-Hc2-Impact, pGEMHc3-Impact and pGEM-Hc4-Impact.

The mature coding regions were excised from their respective pGEM-Hc-Impact vectors with SapI and PstI and ligated into pTWIN1 vector prepared with SapI and PstI. Positive clones were identified by restriction digest and termed pTWIN-Hc1 to 4 . All positive clones were sequenced with the SsPDnaB intein sequencing primer (5'-ACTGGGACTCCATCGTTTCT-3') to confirm the in-frame fusion between the CBD and the Hc-AFPs.

Recombinant production of the Hc-AFPs was performed in E. coli strain BL21DE3 Rosetta gami pLysS, which contains a plasmid encoding for 6 rare codons present in E. coli. pTWIN-Hc1 to 4 was transformed into the BL21 strain using a heat shock method and positive transformants were identified by plating onto LB agar plates containing $34 \mu \mathrm{g} \mathrm{ml}^{-1}$ chloramphinicol, $12.5 \mu \mathrm{g} \mathrm{ml}{ }^{-1}$ tetracycline, $15 \mu \mathrm{g} \mathrm{ml}^{-1}$ kanamycin and 100 $\mu \mathrm{g} \mathrm{ml}^{-1}$ ampicillin. Ten colonies of each construct were inoculated into a $5 \mathrm{ml}$ preculture of LB broth containing the above mentioned antibiotics and incubated over night at $37^{\circ} \mathrm{C}$. Four $2 \mathrm{~L}$ erlenmeyer flasks containing 400 $\mathrm{ml} \mathrm{LB}$ broth plus antibiotics were inoculated with $1 \mathrm{ml}$ preculture and incubated at $37^{\circ} \mathrm{C}$ with continuous shaking at $175 \mathrm{rpm}$. When the $\mathrm{OD}_{600}$ reached 0.7 , the cultures were cooled to room temperature $\left(22^{\circ} \mathrm{C}\right)$ and recombinant production of Hc-AFPs was induced with $0.4 \mathrm{mM}$ IPTG (Roche Diagnostics GmbH, Mannheim, Germany). Recombinant production of Hc-AFPs was allowed to proceed for 6 hours at room temperature with continuous shaking at $175 \mathrm{rpm}$.

\section{Purification of Recombinant Hc-AFP defensins}

Cells were collected from induced cultures by centrifugation. The cell pellet were resuspended in $40 \mathrm{ml}$ cold column binding buffer ( $50 \mathrm{mM}$ Tris- $\mathrm{HCl} \mathrm{pH} \mathrm{8.5,} 1 \mathrm{M}$ $\mathrm{NaCl}$ ) supplemented with $5 \mathrm{mM} \mathrm{MgCl}$ and $0.2 \mathrm{mM}$ PMSF (Roche Diagnostics GmbH, Mannheim, Germany). The cells were broken open by several cycles of freeze-thawing in liquid nitrogen and a $25^{\circ} \mathrm{C}$ water bath. The viscosity of the crude lysate was reduced by adding 50 units of DNaseI enzyme and incubation for $20 \mathrm{~min}$ at room temperature. The lysate was cleared of particulate matter by centrifugation at $10000 \mathrm{rpm}$, at $4^{\circ} \mathrm{C}$ for $30 \mathrm{~min}$.

Recombinant Hc-AFPs were purified using affinity chromatography. The cleared lysate was passed over a $100 \times 10$ mm chitin bead column (New England Biolabs, Ipswich, MA, USA) equilibrated with column binding buffer at $4^{\circ} \mathrm{C}$. The column was loaded using gravity flow and a reduced flow rate of $500 \mu \mathrm{l} \mathrm{min}{ }^{-1}$. The column was washed with $200 \mathrm{ml}$ of binding buffer at a flow rate of $3 \mathrm{ml} \mathrm{min}^{-1}$, followed by a quick flush of $20 \mathrm{ml}$ cleavage buffer ( $\left.200 \mathrm{mM} \mathrm{NH}_{4} \mathrm{OAc} \mathrm{pH} 6.0\right)$. After the column was flushed with cleavage buffer, self cleavage of the intein peptide was induced by temperature shift to $30^{\circ} \mathrm{C}$ for 48 hours.

Cleaved peptide was eluted with $50 \mathrm{ml}$ of cleavage buffer and freeze-dried. The freeze-dried peptide was subjected to a further two rounds of dissolving in 100 $\mathrm{ml} \mathrm{MilliQ}$ water and freeze drying to remove most of the volatile ammonium salt. The peptide was finally dissolved in $2 \mathrm{ml}$ MilliQ water followed by heat treatment at $80^{\circ} \mathrm{C}$ for $15 \mathrm{~min}$ to denature contaminant proteins. 
The sample was centrifuged at $12000 \mathrm{rpm}$ for $20 \mathrm{~min}$ and desalted on an Isolute C8 (EC) column (Biotage AB, Switzerland). The desalted peptide was eluted with $50 \%$ (v/v) acetonitrile and freeze-dried. Purified Hc-AFPs was dissolved in MilliQ water at a final concentration of 1 $\mathrm{mg} \mathrm{ml}^{-1}$.

\section{Analysis and identification of recombinant Hc-AFP defensins}

The purity of eluted Hc-AFPs was evaluated by separating $0.5 \mu \mathrm{g}$ peptide on a $15 \%$ [w/v] Tris-Tricine gel [106]; after separation the peptide bands were visualized by silver staining.

Purified Hc-AFPs were subjected to LC-MS analysis to confirm that the plant defensins purified originated from their respective gene constructs. $10 \mu \mathrm{l}$ purified Hc-AFP peptide was injected on a Waters Alliance 2690 Gradient UPLC and separated on a Waters UPLC BEH C18 column $(2.1 \times 50 \mathrm{~mm}, 1.7 \mu \mathrm{m})$ (Waters Corporation Milford MA, USA). The column was eluted with the program listed in Additional File 7. The eluted peak was submitted to MS analysis on a Waters API Q-TOF Ultima with the following settings: Source, ESI+; Capillary voltage, $3.5 \mathrm{kV}$; Cone voltage, 35; RF1, 40; Source, $100^{\circ} \mathrm{C}$; Desolvation Temp, $350^{\circ} \mathrm{C}$; Desolvation gas, $400 \mathrm{~L}$ $\mathrm{h}^{-1}$ and Cone gas: $50 \mathrm{~L} \mathrm{~h}^{-1}$. The $\mathrm{m} / \mathrm{z}$ ratios obtained were used to calculate the mono-isotopic mass of each peptide with all cysteine residues in an oxidized state. The mass obtained for each peptide was compared to the predicted mono-isotopic mass for each peptide generated with the Expasy-Compute $\mathrm{pI} / \mathrm{Mw}$ tool (Table 1).

\section{Antifungal activity of Hc-AFPs}

Quantitative antifungal activity of the Hc-AFPs was assessed using a microspectrophotometric assay [107]. The assay was performed in a 96-well microtiter plate (Bibby Sterilin Ltd, Stone, Staffs, UK), where each well contained 1000 fungal spores in $100 \mu \mathrm{l}$ half strength Potato Dextrose Broth (PDB) and purified Hc-AFPs concentrations ranging from $5-25 \mu \mathrm{g} \mathrm{ml}^{-1}$. Control reactions contained no peptide. Plates were incubated in the dark at $23^{\circ} \mathrm{C}$ for 3 days, with microspectrophotometric readings taken every 24 hours at $A_{595}$. Hc-AFP defensin activity was scored after $48 \mathrm{~h}$ and expressed in terms of $\%$ growth inhibition as described previously [107].

Microscopical analysis was conducted on $B$. cinerea grown in the presence of $25 \mu \mathrm{g} \mathrm{ml} \mathrm{m}^{-1} \mathrm{Hc}$-AFP1 and 3, 15 $\mu \mathrm{g} \mathrm{ml}^{-1} \mathrm{Hc}$-AFP2 and $18 \mu \mathrm{g} \mathrm{ml}^{-1} \mathrm{Hc}$-AFP4. F. solani was grown in the presence of $25 \mu \mathrm{g} \mathrm{ml}^{-1} \mathrm{Hc}$-AFP1 and 3 and $12 \mu \mathrm{g} \mathrm{ml}^{-1} \mathrm{Hc}$-AFP2 and 4. Microscopical assays were conducted in $200 \mu \mathrm{l}$ reactions containing 1000 fungal spores in half strength PDB. After $48 \mathrm{~h}$ of growth at $23^{\circ} \mathrm{C}$, the samples were treated with Anexin $\mathrm{V}$ and propidium iodide from an ApoAlert ${ }^{\mathrm{TM}}$ Annexin $\mathrm{V}$ Apoptosis Kit (Clonetech, Takara Bio Inc, Japan) before images were captured on an Olympus IX81 inverted microscope and analyzed with the CellIR ${ }^{\circledR}$ software (Olympus Soft Imaging Solutions $\mathrm{GmbH}$ ). Fluorescent images were captured with an intensity of $78 \%$ and an exposure time of $880 \mathrm{msec}^{-1}$. Constant background subtraction, with a setting of 10 , was performed on all captured images.

\section{Additional material}

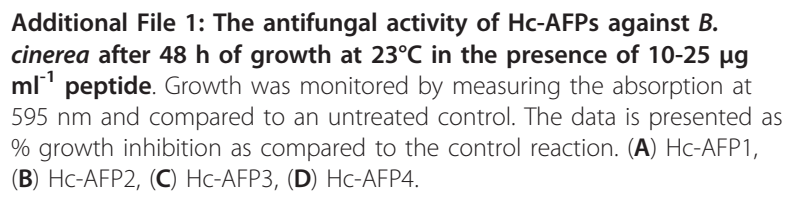

Additional File 2: The antifungal activity of Hc-AFPs against $F$. solani after $48 \mathrm{~h}$ of growth at $23^{\circ} \mathrm{C}$ in the presence of $10-25 \mu \mathrm{g} \mathrm{ml} l^{-1}$ peptide. Growth was monitored by measuring the absorption at $595 \mathrm{~nm}$ and compared to an untreated control. The data is presented as \% growth inhibition as compared to the control reaction. (A) Hc-AFP1, (B) HC-AFP2, (C) HC-AFP3, (D) HC-AFP4.

Additional File 3: Combined overlay of the light microscopical analysis at $10 \times$ magnification and the cell permeabilization assay conducted on $B$. cinerea grown in the presence of Hc-AFPs for $48 \mathrm{~h}$ at $23^{\circ} \mathrm{C}$. (A) HC-AFP1 $25 \mathrm{\mu g} \mathrm{ml}^{-1}$, (B) Hc-AFP2 $15 \mathrm{\mu g} \mathrm{ml}^{-1}$, (C) Untreated control, (D) Hc-AFP3 $25 \mathrm{\mu g} \mathrm{ml}^{-1}$, (E) Hc-AFP4 $18 \mathrm{\mu g} \mathrm{ml}^{-1}$. The yellow indicates a compromised membrane and clearly shows the leakage of the cellular content into the surrounding medium.

Additional File 4: Combined overlay of the light microscopical analysis at 10x magnification and the cell permeabilization assay conducted on $F$. solani grown in the presence of Hc-AFPs for $48 \mathrm{~h}$ at $23^{\circ} \mathrm{C}$. (A) HC-AFP1 $25 \mathrm{\mu g} \mathrm{ml}^{-1}$, (B) Hc-AFP2 $12 \mathrm{\mu g} \mathrm{ml}^{-1}$, (C) Untreated control, (D) HC-AFP3 $25 \mathrm{\mu g} \mathrm{ml}^{-1}$, (E) Hc-AFP4 $12 \mathrm{\mu g} \mathrm{ml}^{-1}$. The yellow indicates a compromised membrane.

Additional File 5: Alignment of the first $\mathbf{5 0}$ nucleotides of genes encoding for plant defensins belonging to the Brassicaceae family. The high level of homology within the region encoding for the signal peptide was exploited to design primer SPDEF-5 (indicated in bold).

Additional File 6: Primers used in the construction of the bacterial expression vectors.

Additional File 7: The elution program used on BEH C18 column during LC-MS analysis.

\section{Acknowledgements and funding}

We would like to thank the following members of the Central Analytical Facility at Stellenbosch University, Dr M Stander for the LC-MS analysis and Dr B Loos for the live cell imaging microscopy. Special thanks to Drs PR Young and JP Moore for critical reading of the manuscript. The work was financially supported by the National Research Foundation (NRF), the Wine Industry Network of Expertise and Technology (Winetech), the South African Table Grape Industry (SATI) and the South African Technology and the Human Resources for Industry Programme (THRIP).

\section{Authors' contributions}

MAV supervised the work and helped with conceptual design and manuscript preparation as well as final data analysis. AdB performed conceptual and experimental design and was responsible for all the research procedures, data analysis and writing the paper. Both authors read and approved the final manuscript. 


\section{Competing interests}

The authors declare that they have no competing interests.

Received: 12 September 2011 Accepted: 28 October 2011

Published: 28 October 2011

\section{References}

1. Dixon R, Harrison M, Lamb C: Early events in the activation of plant defense responses. Annu Rev Phytopathol 1994, 32:479-501.

2. Kuc J: Compounds from plants that regulate or participate in disease resistance. Boioactive compounds from plants Wiley, Chichester (Ciba Found Symp 154) 1990, 213-228.

3. Kuc J: Antifungal compounds in plants.Edited by: HN Nigg and D siegler Phytochemical resources for medicine and agriculture Plenum Press, New york, NY; 1992:159-184

4. Kuc J: Phytoalexins, stress metabolism and disease resistance in plants. Annu Rev Phytopathol 1995, 33:275-297.

5. Osbourn A: Saponins and plant defence - a soap story. TRENDS Plant Sci 1996, 1:4-9.

6. Osbourn AE: Preformed Antimicrobial Compounds and Plant Defense against Fungal Attack. Plant Cell 1996, 8(10):1821-1831.

7. Prost I, Dhondt S, Rothe G, Vicente J, Rodriguez MJ, Kift N, Carbonne F, Griffiths G, Esquerre-Tugaye MT, Rosahl S, et al: Evaluation of the antimicrobial activities of plant oxylipins supports their involvement in defense against pathogens. Plant Physiol 2005, 139(4):1902-1913.

8. van Loon LC, Rep M, Pieterse CM: Significance of inducible defenserelated proteins in infected plants. Annu Rev Phytopathol 2006, 44:135-162.

9. da Cunha L, McFall AJ, Mackey D: Innate immunity in plants: a continuum of layered defenses. Microbes and Infection 2006, 8(5):1372-1381.

10. Lay FT, Anderson MA: Defensins-components of the innate immune system in plants. Curr Protein Pept Sci 2005, 6(1):85-101.

11. Jones DA, Takemoto D: Plant innate immunity - direct and indirect recognition of general and specific pathogen-associated molecules. Curr Opin Immunol 2004, 16(1):48-62.

12. Flors C, Nonell S: Light and singlet oxygen in plant defense against pathogens: phototoxic phenalenone phytoalexins. Acc Chem Res 2006, 39(5):293-300.

13. Yamaguchi T, Minami E, Ueki J, Shibuya N: Elicitor-induced activation of phospholipases plays an important role for the induction of defense responses in suspension-cultured rice cells. Plant Cell Physiol 2005, 46(4):579-587.

14. Broekaert WF, Terras FR, Cammue BP, Osborn RW: Plant defensins: novel antimicrobial peptides as components of the host defense system. Plant Physiol 1995, 108(4):1353-1358.

15. Cammue BP, De Bolle MF, Schoofs HM, Terras FR, Thevissen K, Osborn RW, Rees SB, Broekaert WF: Gene-encoded antimicrobial peptides from plants. 1994, 186:91-106.

16. De Samblanx GW, Goderis IJ, Thevissen K, Raemaekers R, Fant F, Borremans F, Acland DP, Osborn RW, Patel S, Broekaert WF: Mutational analysis of a plant defensin from radish (Raphanus sativus L.) reveals two adjacent sites important for antifungal activity. J Biol Chem 1997, 272(2):1171-1179.

17. Fant F, Vranken W, Broekaert W, Borremans F: Determination of the threedimensional solution structure of Raphanus sativus antifungal protein 1 by 1H NMR. J Mol Biol 1998, 279(1):257-270.

18. Garcia-Olmedo F, Molina A, Alamillo JM, Rodriguez Palenzuela P: Plant defense peptides. Biopolymers- 1998, 47(6):479-491.

19. Padovan L, Segat L, Tossi A, Antcheva N, Benko-Iseppon AM, Ederson AK, Brandao L, Calsa T, Crovella S: A plant-defensin from sugarcane (Saccharum spp.). Protein Pept Lett 2009, 16(4):430-436.

20. Padovan L, Segat L, Tossi A, Calsa T, Ederson AK, Brandao L, Guimaraes RL, Pandolfi V, Pestana-Calsa MC, Belarmino LC, et al: Characterization of a new defensin from cowpea (Vigna unguiculata (L.) Walp.). Protein Pept Lett 2010, 17(3):297-304.

21. Thomma BP, Cammue BP, Thevissen K: Plant defensins. Planta 2002, 216(2):193-202.

22. Castro MS, Fontes W: Plant defense and antimicrobial peptides. Protein Pept Lett 2005, 12(1):13-18.

23. Melo FR, Rigden DJ, Franco OL, Mello LV, Ary MB, Grossi de Sa MF, Bloch C $\mathrm{Jr}$ : Inhibition of trypsin by cowpea thionin: characterization, molecular modeling, and docking. Proteins 2002, 48(2):311-319.
24. Thevissen K, Ghazi A, De Samblanx GW, Brownlee C, Osborn RW, Broekaert WF: Fungal membrane responses induced by plant defensins and thionins. J Biol Chem 1996, 271(25):15018-15025.

25. Florack DEA, Stiekema WJ: Thionins: properties, possible biological roles and mechanisms of action. Plant Mol Biol 1994, 26(1):25-37.

26. Bohlmann H, Apel K: Thionins. Annu Rev Plant Physiol Plant Mol Biol 1991, 42:227-240.

27. Reimann-Philipp U, Schrader G, Martinoia E, Barkholt V, Apel K: Intracellular thionins of barley. A second group of leaf thionins closely related to but distinct from cell wall-bound thionins. J Biol Chem 1989, 264(15):8978-8984.

28. Yokoyama S, Kato K, Koba A, Minami Y, Watanabe K, Yagi F: Purification, characterization, and sequencing of antimicrobial peptides, Cy-AMP1, Cy-AMP2, and Cy-AMP3, from the Cycad (Cycas revoluta) seeds. Peptides 2008, 29(12):2110-2117.

29. Chou M-X, Wei X-Y, Chen D-S, Zhou J-C: Thirteen nodule-specific or nodule-enhanced genes encoding products homologous to cysteine cluster proteins or plant lipid transfer proteins are identified in Astragalus sinicus L. by suppressive subtractive hybridization. J Exp Bot 2006, 57(11):2673-2685.

30. Wijaya R, Neumann GM, Condron R, Hughes AB, Polya GM: Defense proteins from seed of Cassia fistula include a lipid transfer protein homologue and a protease inhibitory plant defensin. Plant Sci 2000, 159(2):243-255.

31. Charvolin D, Douliez J, Marion D, Cohen-Addad C, Pebay-Peyroula E: The crystal structure of a wheat nonspecific lipid transfer protein (ns-LTP1) complexed with two molecules of phospholipid at 2.1 A resolution. Eur J Biochem 1999, 264:562-568.

32. Kader J-C: Lipid-transfer proteins in plants. Annu Rev Plant Physiol Plant Mol Biol 1996, 47:627-654.

33. Molina A, Segura A, Garcia-Olmedo F: Lipid transfer proteins (nsLTPs) from barley and maize leaves are potent inhibitors of bacterial and fungal plant pathogens. FEBS Lett 1993, 316(2):119-122.

34. Wirtz K, Gadella T Jr: Properties and modes of action of specific and nonspecific phospholipid transfer proteins. Experentia 1990, 46:592-599.

35. Shiau YS, Horng SB, Chen CS, Huang PT, Lin C, Hsueh YC, Lou KL: Structural analysis of the unique insecticidal activity of novel mungbean defensin VrD1 reveals possibility of homoplasy evolution between plant defensins and scorpion neurotoxins. J Mol Recognit 2006, 19:441-450.

36. Liu YJ, Cheng CS, Lai SM, Hsu MP, Chen CS, Lyu PC: Solution structure of the plant defensin $\mathrm{VrD1}$ from mung bean and its possible role in insecticidal activity against bruchids. Proteins 2006, 63(4):777-786.

37. Lay FT, Schirra HJ, Scanlon MJ, Anderson MA, Craik DJ: The threedimensional solution structure of $\mathrm{NaD1}$, a new floral defensin from Nicotiana alata and its application to a homology model of the crop defense protein alfAFP. J Mol Biol 2003, 325(1):175-188.

38. Yang YF, Cheng KC, Tsai PH, Liu CC, Lee TR, Lyu PC: Alanine substitutions of noncysteine residues in the cysteine-stabilized alphabeta motif. Protein Sci 2009, 18(7):1498-1506.

39. Zhu S, Gao B, Tytgat J: Phylogenetic distribution, functional epitopes and evolution of the CSab superfamily. Cell Mol Life Sci 2005, 62:2257-2269.

40. Tamaoki H, Miura R, Kusunoki M, Kyogoku Y, Kobayashi Y, Moroder L: Folding motifs induced and stabilized by distinct cystine frameworks. Prot Eng 1998, 11:649-659.

41. Kobayashi Y, Sato A, Takashima H, Tamaoki H, Nishimura S, Kyogoku Y, Ikenaka K, Kondo I, Mikoshiba K, Hojo H, et al: A new alpha -helical motif in membrane active peptides. Neurochem Internat 1991, 18:523-534.

42. Terras FRG, Eggermont K, Kovaleva V, Raikhel NV, Osborn RW, Kester A, Rees SB, Torrekens S, Leuven Fv, Vanderleyden J, et al: Small cysteine-rich antifungal proteins from radish: their role in host defense. Plant Cell 1995, 7(5):573-588

43. Terras FR, Torrekens S, Van Leuven F, Osborn RW, Vanderleyden J, Cammue BP, Broekaert WF: A new family of basic cysteine-rich plant antifungal proteins from Brassicaceae species. FEBS Lett 1993, 316(3):233-240.

44. Kovalchuk N, Li M, Wittek F, Reid N, Singh R, Shirley N, Ismagul A, Eliby S, Johnson A, Milligan AS, et al: Defensin promoters as potential tools for engineering disease resistance in cereal grains. Plant Biotechnol J 2010, 8(1):47-64.

45. Bahramnejad B, Erickson LR, Atnaseo C, Goodwin PH: Differential expression of eight defensin genes of $\mathrm{N}$. benthamiana following biotic 
stress, wounding, ethylene, and benzothiadiazole treatments. Plant Cell Rep 2009, 28(4):703-717.

46. Hanks JN, Snyder AK, Graham MA, Shah RK, Blaylock LA, Harrison MJ, Shah DM: Defensin gene family in Medicago truncatula: structure, expression and induction by signal molecules. Plant Mol Biol 2005, 58(3):385-399.

47. de Beer A, Vivier MA: Vv-AMP1, a ripening induced peptide from Vitis vinifera shows strong antifungal activity. BMC Plant Biol 2008, 8:75.

48. Meyer B, Houlne G, Pozueta-Romero J, Schantz ML, Schantz R: Fruit-specific expression of a defensin-type gene family in bell pepper. Upregulation during ripening and upon wounding. Plant Physiol 1996, 112(2):615-622

49. Oh BJ, Ko MK, Kostenyuk I, Shin B, Kim KS: Coexpression of a defensin gene and a thionin-like via different signal transduction pathways in pepper and Colletotrichum gloeosporioides interactions. Plant Mol Biol 1999, 41(3):313-319.

50. Stotz HU, Spence B, Wang Y: A defensin from tomato with dual function in defense and development. Plant Mol Biol 2009, 71:(1-2):131-143.

51. Lay FT, Brugliera F, Anderson MA: Isolation and properties of floral defensins from ornamental tobacco and petunia. Plant Physiol 2003, 131(3):1283-1293.

52. Janssen BJ, Schirra HJ, Lay FT, Anderson MA, Craik DJ: Structure of Petunia hybrida defensin 1, a novel plant defensin with five disulfide bonds. Biochemistry 2003, 42(27):8214-8222.

53. Park HC, Kang YH, Chun HJ, Koo JC, Cheong YH, Kim CY, Kim MC, Chung WS, Kim JC, Yoo JH, et al: Characterization of a stamen-specific CDNA encoding a novel plant defensin in Chinese cabbage. Plant Mol Biol 2002, 50(1):59-69.

54. Urdangarin MC, Norero NS, Broekaert WF, de ICL: A defensin gene expressed in sunflower inflorescence. Plant Physiology and Biochemistry 2000, 38(3):253-258.

55. Karunanandaa B, Singh A, Kao TH: Characterization of a predominantly pistil-expressed gene encoding a gamma-thionin-like protein of Petunia inflata. Plant Mol Biol 1994, 26(1):459-464.

56. Hiruma K, Nishiuchi T, Kato T, Bednarek P, Okuno T, Schulze-Lefert P, Takano Y: Arabidopsis ENHANCED DISEASE RESISTANCE 1 is required for pathogen-induced expression of plant defensins in nonhost resistance and acts through interference of MYC2-mediated repressor function. Plant J 2011

57. Amien S, Kliwer I, Márton ML, Debener T, Geiger D, Becker D, Dresselhaus T: Defensin-Like ZmES4 Mediates Pollen Tube Burst in Maize via Opening of the Potassium Channel KZM1. PLoS Biol 2010, 8(6):e1000388.

58. Nielsen ME, Lok F, Nielsen HB: Distinct developmental defense activations in barley embryos identified by transcriptome profiling. Plant $\mathrm{Mol} B i \mathrm{O}$ 2006, 61(4-5):589-601.

59. Franco OL, Murad AM, Leite JR, Mendes PAM, Prates MV, Bloch C: Identification of a cowpea gamma-thionin with bactericidal activity. FEBS J 2006, 273(15):3489-3497.

60. Segura A, Moreno M, Molina A, Garcia-Olmedo F: Novel defensin subfamily from spinach (Spinacia oleracea). FEBS Lett 1998, 435(23):159-162.

61. Lin $\mathrm{P}$, Wong $\mathrm{JH}, \mathrm{Ng} \mathrm{TB}$ : A defensin with highly potent antipathogenic activities from the seeds of purple pole bean. Biosci Rep 2010, 30(2):101-109.

62. Aerts AM, Carmona-Gutierrez D, Lefevre S, Govaert G, Francois IE, Madeo F, Santos R, Cammue BP, Thevissen K: The antifungal plant defensin RsAFP2 from radish induces apoptosis in a metacaspase independent way in Candida albicans. FEBS Lett 2009, 583(15):2513-2516.

63. Tavares PM, Thevissen K, Cammue BP, Francois IE, Barreto-Bergter E, Taborda CP, Marques AF, Rodrigues ML, Nimrichter L: In vitro activity of the antifungal plant defensin RsAFP2 against Candida isolates and its in vivo efficacy in prophylactic murine models of candidiasis. Antimicrob Agents Chemother 2008, 52(12):4522-4525.

64. Games PD, Dos Santos IS, Mello EO, Diz MS, Carvalho AO, de SouzaFilho GA, Da Cunha M, Vasconcelos IM, Ferreira Bdos S, Gomes VM: Isolation, characterization and cloning of a CDNA encoding a new antifungal defensin from Phaseolus vulgaris L. seeds. Peptides 2008, 29(12):2090-2100.

65. Portieles R, Ayra C, Gonzalez E, Gallo A, Rodriguez R, Chacón O, López Y, Rodriguez M, Castillo J, Pujol M, et al: NmDef02, a novel antimicrobial gene isolated from Nicotiana megalosiphon confers high-level pathogen resistance under greenhouse and field conditions. Plant Biotechnol $J$ 2010, 8(6):678-690.

66. Kanzaki H, Nirasawa S, Saitoh H, Ito M, Nishihara M, Terauchi R, Nakamura I: Overexpression of the wasabi defensin gene confers enhanced resistance to blast fungus (Magnaporthe grisea) in transgenic rice. Theor Appl Genet 2002, 105(6-7):809-814.

67. van der Weerden NL, Hancock REW, Anderson MA: Permeabilization of Fungal Hyphae by the Plant Defensin NaD1 Occurs through a Cell Walldependent Process. J Biol Chem 2010, 285(48):37513-37520.

68. Jha S, Chattoo BB: Expression of a plant defensin in rice confers resistance to fungal phytopathogens. Transgenic Res 2010, 19(3):373-384.

69. Kovaleva V, Kiyamova R, Cramer R, Krynytskyy H, Gout I, Filonenko V, Gout R: Purification and molecular cloning of antimicrobial peptides from Scots pine seedlings. Peptides 2009, 30(12):2136-2143.

70. Jha S, Tank HG, Prasad BD, Chattoo BB: Expression of Dm-AMP1 in rice confers resistance to Magnaporthe oryzae and Rhizoctonia solani. Transgenic Res 2009, 18(1):59-69.

71. Terras F, Schoofs H, De Bolle M, Van Leuven F, Rees S, Vanderleyden J, Cammue B, Broekaert W: Analysis of two novel classes of plant antifungal proteins from radish (Raphanus sativus L) seeds. Journal Biol Chem 1992, 267(22):15301-15309.

72. Bloch C Jr, Richardson M: A new family of small $(5 \mathrm{kD})$ protein inhibitors of insect alpha-amylase from seeds of sorghum (Sorghum bicolor (L.) Moench) have sequence homologies with wheat gamma-purothionins. FEBS Lett 1991, 279:101-104.

73. Leung EH, Wong $\mathrm{JH}, \mathrm{Ng} \mathrm{TB}$ : Concurrent purification of two defense proteins from French bean seeds: a defensin-like antifungal peptide and a hemagglutinin. J Pept Sci 2008, 14(3):349-353.

74. Ngai PH, Ng TB: Phaseococcin, an antifungal protein with antiproliferative and anti-HIV-1 reverse transcriptase activities from small scarlet runner beans. Biochem Cell Biol 2005, 83(2):212-220.

75. Wong JH, Ng TB: Gymnin, a potent defensin-like antifungal peptide from the Yunnan bean (Gymnocladus chinensis Baill). Peptides 2003, 24(7):963-968.

76. Wong JH, Ng TB: Sesquin, a potent defensin-like antimicrobial peptide from ground beans with inhibitory activities toward tumor cells and HIV-1 reverse transcriptase. Peptides 2005, 26(7):1120-1126.

77. Choi MS, Kim YH, Park HM, Seo BY, Jung JK, Kim ST, Kim MC, Shin DB, Yun HT, Choi IS, et al: Expression of BrD1, a plant defensin from Brassica rapa, confers resistance against brown planthopper (Nilaparvata lugens) in transgenic rices. Mol Cells 2009, 28(2):131-137.

78. Pelegrini PB, Lay FT, Murad AM, Anderson MA, Franco OL: Novel insights on the mechanism of action of alpha-amylase inhibitors from the plant defensin family. Proteins 2008, 73(3):719-729.

79. de Zélicourt A, Letousey $P$, Thoiron S, Campion C, Simoneau P, Elmorjani K, Marion D, Simier P, Delavault P: Ha-DEF1, a sunflower defensin, induces cell death in Orobanche parasitic plants. Planta 2007, 226(3):592-600.

80. Mirouze M, Sels J, Richard O, Czernic P, Loubet S, Jacquier A, Francois IEJA, Cammue BPA, Lebrun $M$, Berthomieu $P$, et al: A putative novel role for plant defensins: a defensin from the zinc hyper-accumulating plant, Arabidopsis halleri, confers zinc tolerance. Plant J 2006, 47(3):329-342.

81. Silverstein KA, Graham MA, Paape TD, VandenBosch KA: Genome organization of more than 300 defensin-like genes in Arabidopsis. Plant Physiol 2005, 138(2):600-610.

82. Gao AG, Hakimi SM, Mittanck CA, Wu Y, Woerner BM, Stark DM, Shah DM, Liang J, Rommens CM: Fungal pathogen protection in potato by expression of a plant defensin peptide. Nat Biotechnol 2000, 18(12):1307-1310.

83. Khan RS, Nakamura I, Mii M: Development of disease-resistant marker-free tomato by R/RS site-specific recombination. Plant Cell Rep 2011, 30(6):1041-1053.

84. Thomma BP, Cammue BP, Thevissen K: Mode of action of plant defensins suggests therapeutic potential. Curr Drug Targets Infect Disord 2003, $3(1): 1-8$

85. Terras FR, Eggermont K, Kovaleva V, Raikhel NV, Osborn RW, Kester A, Rees SB, Torrekens S, Van Leuven F, Vanderleyden J, et al: Small cysteinerich antifungal proteins from radish: their role in host defense. Plant Cell 1995, 7(5):573-588.

86. Schaaper WM, Posthuma GA, Plasman HH, Sijtsma L, Fant F, Borremans FA, Thevissen K, Broekaert WF, Meloen RH, van Amerongen A: Synthetic peptides derived from the beta2-beta3 loop of Raphanus sativus 
antifungal protein 2 that mimic the active site. J Pept Res 2001, 57(5):409-418.

87. De Samblanx GW, Fernandez del Carmen A, Sijtsma L, Plasman HH, Schaaper WM, Posthuma GA, Fant F, Meloen RH, Broekaert WF, van Amerongen A: Antifungal activity of synthetic 15-mer peptides based on the Rs-AFP2 (Raphanus sativus antifungal protein 2) sequence. Pept Res 1996, 9(6):262-268

88. Sagaram US, Pandurangi R, Kaur J, Smith TJ, Shah DM: Structure-activity determinants in antifungal plant defensins MsDef1 and MtDef4 with different modes of action against Fusarium graminearum. PLoS One 2011, 6(4):e18550.

89. de Paula VS, Razzera G, Barreto-Bergter E, Almeida FC, Valente AP: Portrayal of complex dynamic properties of sugarcane defensin 5 by NMR: multiple motions associated with membrane interaction. Structure 2011, 19(1):26-36.

90. de Medeiros LN, Angeli R, Sarzedas CG, Barreto-Bergter E, Valente AP, Kurtenbach E, Almeida FCL: Backbone dynamics of the antifungal Psd1 pea defensin and its correlation with membrane interaction by NMR spectroscopy. Biochim et Biophys Acta (BBA) - Biomembranes 2010, 1798(2):105-113.

91. Kovaleva V, Krynytskyy H, Gout I, Gout R: Recombinant expression, affinity purification and functional characterization of Scots pine defensin 1. Appl Microbiol Biotechnol 2010, 1-9.

92. Dos Santos IS, Carvalho Ade O, de Souza-Filho GA, do Nascimento W, Machado OL, Gomes VM: Purification of a defensin isolated from Vigna unguiculata seeds, its functional expression in Escherichia coli, and assessment of its insect alpha-amylase inhibitory activity. Protein Expr Purif 2010, 71(1):8-15.

93. Finkina El, Shramova El, Tagaev AA, Ovchinnikova TV: A novel defensin from the lentil Lens culinaris seeds. Biochem Biophys Res Commun 2008, 371(4):860-865.

94. Chen KC, Lin CY, Kuan CC, Sung HY, Chen CS: A novel defensin encoded by a mungbean CDNA exhibits insecticidal activity against bruchid. J Agric Food Chem 2002, 50(25):7258-7263.

95. Garcia-Olmedo F, Molina A, Alamillo JM, Rodriguez-Palenzuela P: Plant defense peptides. Biopolymers 1998, 47(6):479-491.

96. Thevissen K, Warnecke DC, Francois IE, Leipelt M, Heinz E, Ott C, Zahringer U, Thomma BP, Ferket KK, Cammue BP: Defensins from insects and plants interact with fungal glucosylceramides. J Biol Chem 2004, 279(6):3900-3905.

97. Chang S, Puryear J, Cairney J: A Simple and Efficient Method for Isolating RNA from Pine Trees. Plant Mol Biol Report 1993, 11:113-116.

98. Hall T: BioEdit: a user-friendly biological sequence alignment editor and analysis program for Windows 95/98/NT. 41. Nucl Acids Symp Ser 1999, 41:95-98.

99. Thompson JD, Gibson TJ, Plewniak F, Jeanmougin F, Higgins DG: The ClustalX windows interface: flexible strategies for multiple sequence alignment aided by quality analysis tools. Nucl Acids Res 1997, 25:4876-4882.

100. Canutescu A, Dunbrack R Jr: Arbodraw 2006

101. Krieger $E$, Koraimann $G$, Vriend $G$ : Increasing the precision of comparative models with YASARA NOVA - a self-parameterizing force field. Proteins 2002, 47:393-402.

102. Krieger E, Darden T, Nabuurs S, Finkelstein A, Vriend G: Making optimal use of empirical energy functions: force field parameterization in crystal space. Proteins 2004, 57:678-683.

103. Schymkowitz JWH, Rousseau F, Martins IC, Ferkinghoff-Borg J, Stricher F, Serrano L: Prediction of water and metal binding sites and their affinities by using the Fold-X force field. Proc NatAcad Sci USA 2005, 102(29):10147-10152.

104. Pfaffl MW, Horgan GW, Dempfle L: Relative expression software tool $\left(\mathrm{REST}^{\mathrm{O}}\right)$ for group-wise comparison and statistical analysis of relative expression results in real-time PCR. Nucl Acids Res 2002, 30:1-10.

105. Ruijter JM, Ramakers C, Hoogaars WMH, Karlen Y, Bakker O, van den Hoff MJB, Moorman AFM: Amplification efficiency: linking baseline and bias in the analysis of quantitative PCR data. Nucl Acids Res 2009, 37(6): e45.

106. Schagger H, G VJ: Tricine-sodium dodecyl sulfate-polyacrylamide gel electrophoresis for the separation of proteins in the range from 1 to 100 kDa. Anal Biochem 1987, 166:368-379.
107. Broekaert W, Terras F, Cammue B, Vandereyden J: An automated quantitive assay for fungal growth inhibition. FEMS Microbiol Lett 1990, 69:55-60.

doi:10.1186/1756-0500-4-459

Cite this article as: de Beer and Vivier: Four plant defensins from an indigenous South African Brassicaceae species display divergent activities against two test pathogens despite high sequence similarity in the encoding genes. BMC Research Notes 2011 4:459.

\section{Submit your next manuscript to BioMed Central and take full advantage of:}

- Convenient online submission

- Thorough peer review

- No space constraints or color figure charges

- Immediate publication on acceptance

- Inclusion in PubMed, CAS, Scopus and Google Scholar

- Research which is freely available for redistribution

Submit your manuscript at www.biomedcentral.com/submit
C Biomed Central 